\title{
Technology, Safety and Costs of Decommissioning a Reference Boiling Water Reactor Power Station
}

Classification of Decommissioning Wastes

Prepared by E. S. Murphy

Pacific Northwest Laboratory Operated by

Battelle Memorial Institute

Prepared for

U.S. Nuclear Regulatory

Commission

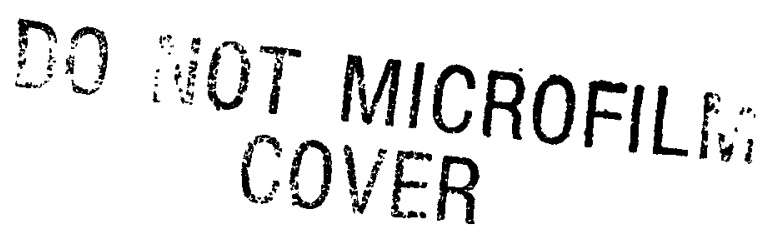




\section{NOTICE}

This report was prepared as an account of work sponsored by an agency of the United States Government. Neither the United States Government nor any agency thereof, or any of their employees, makes any warranty, expressed or implied, or assumes any legal liability of responsibility for any third party's use, or the results of such use, of any information, apparatus, product or process disclosed in this report, or represents that its use by such third party would not infringe privately owned rights.

\section{NOTICE}

Availability of Reference Materials Cited in NRC Publications

Most documents cited in NRC publications will be available from one of the following sources:

1. The NRC Public Document Room, 1717 H Street, N.W. Washington, DC 20555

2. The NRC/GPO Sales Program, U.S. Nuclear Regulatory Commission, Washington, DC 20555

3. The National Technical Information Service, Springfield, VA 22161

Although the listing that follows represents the majority of documents cited in NRC publications, it is not intended to be exhaustive.

Referenced documents available for inspection and copying for a fee from the NRC Public Document Room include NRC correspondence and internal NRC memoranda; NRC Office of Inspection and Enforcement bulletins, circulars, information notices, inspection and investigation notices; Licensee Event Reports; vendor reports and correspondence; Commission papers; and applicant and licensee documents and correspondence.

The following documents in the NUREG series are available for purchase from the NRC/GPO Sales Program: formal NRC staff and contractor reports, NRC-sponsored conference proceedings, and NRC booklets and brochures. Also available are Regulatory Guides, NRC regulations in the Code of Federal Regulations, and Nuclear Regulatory Commission /ssuances.

Documents available from the National Technical Information Service include NUREG series reports and technical reports prepared by other federal agencies and reports prepared by the Atomic Energy Commission, forerunner agency to the Nuclear Regulatory Commission.

Documents available from public and special technical libraries include all open literature items, such as books, journal and periodical articles, and transactions. Federal Register notices, federal and state legislation, and congressional reports can usually be obtained from these libraries.

Documents such as theses, dissertations, foreign reports and translations, and non-NRC conference proceedings are available for purchase from the organization sponsoring the publication cited.

Single copies of NRC draft reports are available free, to the extent of supply, upon written request to the Division of Technical Information and Document Control, U.S. Nuclear Regulatory Commission, Washington, DC 20555.

Copies of industry codes and standards used in a substantive manner in the NRC regulatory process are maintained at the NRC Library, 7920 Norfolk Avenue, Bethesda, Maryland, and are available there for reference use by the public. Codes and standards are usually copyrighted and may be purchased from the originating organization or, if they are American National Standards, from the American National Standards Institute, 1430 Broadway, New York, NY 10018. 


\section{DISCLAIMER}

This report was prepared as an account of work sponsored by an agency of the United States Government. Neither the United States Government nor any agency Thereof, nor any of their employees, makes any warranty, express or implied, or assumes any legal liability or responsibility for the accuracy, completeness, or usefulness of any information, apparatus, product, or process disclosed, or represents that its use would not infringe privately owned rights. Reference herein to any specific commercial product, process, or service by trade name, trademark, manufacturer, or otherwise does not necessarily constitute or imply its endorsement, recommendation, or favoring by the United States Government or any agency thereof. The views and opinions of authors expressed herein do not necessarily state or reflect those of the United States Government or any agency thereof. 


\section{DISCLAIMER}

Portions of this document may be illegible in electronic image products. Images are produced from the best available original document. 


\title{
Technology, Safety and Costs of Decommissioning a Reference Boiling Water Reactor Power Station
}

\author{
Classification of Decommissioning Wastes
}

Manuscript Completed: August 1984

Date Published: September 1984

Prepared by E. S. Murphy

Pacific Northwest Laboratory

Richland, WA 99352

Prepared for

Division of Engineering Technology

Office of Nuclear Regulatory Research

U.S. Nuclear Regulatory Commission

Washington, D.C. 20555

NRC FIN No. B2117

\section{DISCLAIMER}

This report was prepared as an account of work sponsored by an agency of the United States Government. Neither the United States Government nor any agency thereof, nor any of their employees, makes any warranty, express or implied, or assumes any legal habilys, product, or bility for the accuracy, completeness, or usefulness of any inferivately owned rights. Referprocess disclosed, or represents that its use would nocess, or service by trade name, trademark, ence herein to any specific commercial product, procest, or se imply its endorsement, recommanufacturer, or otherwise does not necessarily consticte or any agency thereof. The views mendation, or favoring by the United States Governmessarily state or reflect those of the and opinions of authors expressed herein do not

United States Government or any agency thereof 


\section{NOTICE}

This report was prepared as an account of work sponsored by an agency of the United States Government. Neither the United States Government nor any agency thereof, or any of their employees, makes any warranty, expressed or implied, or assumes any legal liability of responsibility for any third party's use, or the results of such use, of any information, apparatus. product or process disclosed in this report, or represents that its use by such third party would not infringe privately owned rights.

\section{NOTICE}

Availability of Reference Materials Cited in NRC Publications

Most documents cited in NRC publications will be available from one of the following sources:

1. The NRC Public Document Room, 1717 H Street, N.W. Washington, DC 20555

2. The NRC/GPO Sales Program, U.S. Nuclear Regulatory Commission, Washington, DC 20555

3. The National Technical Information Service, Springfield, VA 22161

Although the listing that follows represents the majority of documents cited in NRC publications, it is not intended to be exhaustive.

Referenced documents available for inspection and copying for a fee from the NRC Public Document Room include NRC correspondence and internal NRC memoranda; NRC Office of Inspection and Enforcement bulletins, circulars, information notices, inspection and investigation notices; Licensee Event Reports; vendor reports and correspondence; Commission papers; and applicant and licensee documents and correspondence.

The following documents in the NUREG series are available for purchase from the NRC/GPO Sales Program: formal NRC staff and contractor reports, NRC-sponsored conference proceedings, and NRC booklets and brochures. Also available are Regulatory Guides, NRC regulations in the Code of Federal Regulations, and Nuclear Regulatory Commission Issuances.

Documents available from the National Technical Information Service include NUREG series reports and technical reports prepared by other federal agencies and reports prepared by the Atomic Energy Commission, forerunner agency to the Nuclear Regulatory Commission.

Documents available from public and special technical libraries include all open literature items, such as books, journal and periodical articles, and transactions. Federal Register notices, federal and state legislation, and congressional reports can usually be obtained from these libraries.

Documents such as theses, dissertations, foreign reports and translations, and non-NRC conference proceedings are available for purchase from the organization sponsoring the publication cited.

Single copies of NRC draft reports are avallable free, to the extent of supply, upon written request to the Division of Technical Information and Document Control, U.S. Nuclear Regulatory Com. mission, Washington, DC 20555.

Copies of industry codes and standards used in a substantive manner in the NRC regulatory process are maintained at the NRC Library, 7920 Norfolk Avenue, Bethesda, Maryland, and are available there for reference use by the public. Codes and standards are usually copyrighted and may be purchased from the originating organization or, if they are American National Standards, from the American National Standards Institute, 1430 Broadway. New York, NY 10018. 
FOREWORD

BY

NUCLEAR REGULATORY COMMISSION STAFF

The NRC staff is reappraising its regulatory position relative to the decommissioning of nuclear facilities. (1) As a part of this activity, the NRC has initiated two series of studies through technical assistance contracts. These contracts are being undertaken to develop information to support the preparation of new standards covering decommissioning.

The basic series of studies covers the technology, safety, and costs of decommissioning reference nuclear facilities. Light water reactors and fuelcycle and non-fuel-cycle facilities are included. Facilities of current design on typical sites are selected for the studies. Separate reports are prepared as the studies of the various facilities are completed.

The first report in this series covers a fuel reprocessing plant; (2) the second addresses a pressurized water reactor; $(3)$ and the third deals with a small mixed-oxide fuel fabrication plant. 4 ) The fourth report, an addendum to the pressurized water reactor report, $(5)$ examines the relationship between reactor size and decommissioning cost, the cost of entombment, and the sensitivity of cost to radiation levels, contractual arrangements, and disposal site charges, The fifth report in this series deals with a low-level waste bypjal ground; $(6)$ the sixth covers a large boiling water reactor power station; $(7)$ and the seventh examines a uranium fuel-fabrication plant. (8) The eighth report covers non-fuel-cycle nuclear facilities. 9 ) The ninth report, an addendum to the low-level waste burial ground report, $(10)$ supplements the description of environmental radiological surveillance programs used in the parent document. The tenth report deals with a uranium hexafluoride conversion plant. (11) The eleventh report addresses the decommissioning of nuclear reactors at multiplereactor power stations. (12) The twelfth report covers nuclear research and test reactors. $(13)$ The thirteenth report examines the decommissioning of reference light water reactors that have been involved in serious accidents. (14) The fourteenth and fifteenth reports are addendums to the pressurized water reactor report and the boiling water reactor report, respectively, and examine the impacts on decommissioning of both of these plant types of a temporary inability to dispose of waste offsite at the time of decommissioning. $(15,16)$ The sixteenth report, an addendum to the nuclear research and test reactors report, addresses the sensitivity of decommissioning radiation exposure and costs to selected parameters at nuclear research and test reactor facilities. (17) The seventeenth report deals with the decommissioning of independent spent fuel storage installations. (18) This addendum to the boiling 
water reactor report examines the radioactive wastes expected to result from decommissioning the reference BWR and classifies those wastes in accordance with 10 CFR 61.

An additional decommissioning topic will be reported tentatively as follows:

FY 1984 Post-Accident Decommissioning at Fuel-Cycle and Non-FuelCycle Facilities

The second series of studies covers supporting information on the decommissioning of nuclear facilities. Four reports have been issued in the second series. The first consjsts of an annotated bibliography on the decommissioning of nuclear facilities. (19) The second is a review and analysis of current decommissioning regulations. (20) The third covers the facilitation of the decommissioning of 1 ight water reactors. (21) The fourth report covers the establishment of an information base concerning monitoring for compliance with decommissioning survey criteria. (22) The fifth report addresses the technology and cost of termination surveys associated with decommissioning of nuclear facilities. (23)

The information provided in this report on decommissioning of a boiling water reactor, including any comments, will be included in the record for consideration by the Commission in establishing criteria and new standards for decommissioning. Comments on this report should be mailed to

Chief

Chemical Engineering Branch

Division of Engineering Technology

Office of Nuclear Regulatory Research

U.S. Nuclear Regulatory Commission

Washington, D.C. 20555

\section{REFERENCES}

1. Plan for Reevaluation of NRC Policy on Decommissioning of Nuclear Facilities. NUREG-0436, Rev. 1, Office of Standards Development, U.S. Nuclear Regulatory Commission, December 1978.

2. Technology, Safety and Costs of Decommissioning a Reference Nuclear Fuel Reprocessing Plant. NUREG-0278, Pacific Northwest Laboratory for U.S. Nuclear Regulatory Commission, October 1977. 
3. Technology, Safety and Costs of Decommissioning a Reference Pressurized Water Reactor Power Station. NUREG/CR-0130, Pacific Northwest Laboratory for U.S. Nuclear Regulatory Commission, June 1978.

4. Technology, Safety and Costs of Decommissioning a Reference Small Mixed Oxide Fuel Fabrication Plant. NUREG/CR-0129, Pacific Northwest Laboratory for U.S. Nuclear Regulatory Commission, February 1979.

5. Technology, Safety and Costs of Decommissioning a Reference Pressurized Water Reactor Power Station. NUREG/CR-0130 Addendum, Pacific Northwest Laboratory for U.S. Nuclear Regulatory Commission, August 1979.

6. Technology, Safety and Costs of Decommissioning a Reference Low-Level Waste Burial Ground. NUREG/CR-0570, Pacific Northwest Laboratory for U.S. Nuclear Regulatory Commission, June 1980.

7. Technology, Safety and Costs of Decommissioning a Reference Boiling Water Reactor Power Station. NUREG/CR-0672, Pacific Northwest Laboratory for U.S. Nuclear Regulatory Commission, June 1980.

8. Technology, Safety and Costs of Decommissioning a Reference Uranium Fuel Fabrication Plant. NUREG/CR-1266, Pacific Northwest Laboratory for U.S. Nuclear Regulatory Commission, October 1980.

9. Technology, Safety and Costs of Decommissioning Reference Non-Fuel-Cycle Nuclear Facilities. NUREG/CR-1754, Pacific Northwest Laboratory for U.S. Nuclear Regulatory Commission, February 1981.

10. Technology, Safety and Costs of Decommissioning a Reference Low-Level Waste Burial Ground. NUREG/CR-0570 Addendum, Pacific Northwest Laboratory for U.S. Nuclear Regulatory Commission, May 1981.

11. Technology, Safety and Costs of Decommissioning a Reference Uranium Hexafluoride Conversion Plant. NUREG/CR-1757, Pacific Northwest Laboratory for U.S. Nuclear Regulatory Commission, October 1981.

12. Technology, Safety and Costs of Decommissioning Nuclear Reactors at Multiple-Reactor Stations. NUREG/CR-1755, Pacific Northwest Laboratory for U.S. Nuclear Regulatory Commission, January 1982.

13. Technology, Safety and Costs of Decommissioning Reference Nuclear Research and Test Reactors. NUREG/CR-1756, Pacific Northwest Laboratory for U.S. Nuclear Regulatory Commission, March 1982. 
14. Technology, Safety and Costs of Decommissioning Reference Light Water Reactors Following Postulated Accidents. NUREG/CR-2601, Pacific Northwest Laboratory for U.S. Nuclear Regulatory Commission, November 1982.

15. Technology, Safety and Costs of Decommissioning a Reference Pressurized Water Reactor Power Station. NUREG/CR-0130 Addendum 2, Pacific Northwest Laboratory for U.S. Nuclear Regulatory Commission, June 1983.

16. Technology, Safety and Costs of Decommissioning a Reference Boiling Water Reactor Power Station. NUREG/CR-672 Addendum 1, Pacific Northwest Laboratory for U.S. Nuclear Regulatory Commission, June 1983.

17. Technology, Safety and Costs of Decommissioning Reference Nuclear Research and Test Reactors. NUREG/CR-1756 Addendum, Pacific Northwest Laboratory for U.S. Nuclear Regulatory Commission, July 1983.

18. Technology, Safety and Costs of Decommissioning Reference Independent Spent Fuel Storage Installations. NUREG/CR-2210, Pacific Northwest Laboratory for U.S. Nuclear Regulatory Commission, January 1984.

19. Decommissioning of Nuclear Facilities - An Annotated Bibliography. NUREG/CR-0130, Pacific Northwest Laboratory for U.S. Nuclear Regulatory Commission, August 1979.

20. Decommissioning of Nuclear Facilities - A Review and Analys is of Current Regulations. NUREG/CR-0671, Pacific Northwest Laboratory for U.S. Nuclear Regulatory Commission, August 1979.

21. Facilitation of Decommissioning of Light Water Reactors. NUREG/CR-0569, Pacific Northwest Laboratory for U.S. Nuclear Regulatory Commission, December 1979.

22. Monitoring for Compliance with Decommissioning Termination Survey Criteria. NUREG/CR-2082, Oak Ridge National Laboratory for U.S. Nuclear Regulatory Commission, June 1981.

23. Technology and Cost of Termination Surveys Associated with Decommissioning of Nuclear Facilities. NUREG/CR-2241, Oak Ridge National Laboratory for U.S. Nuclear Regulatory Commission, February 1982. 
STUDY LEADER

E. S. Murphy

STUDY CONTRIBUTORS

E. S. Murphy

R. I. Smith

EDITOR

S. F. Liebetrau 



\section{ABSTRACT}

The radioactive wastes expected to result from decommissioning of the reference boiling water reactor power station are reviewed and classified in accordance with 10 CFR 61.

The 18,949 cubic meters of waste from DECON are classified as follows: Class $\mathrm{A}, 97.5 \%$; Class $\mathrm{B}, 2.0 \%$; Class $\mathrm{C}, 0.3 \%$. About $0.2 \%$ ( 47 cubic meters) of the waste would be generally unacceptable for disposal using near-surface disposal methods. 


\section{CONTENTS}

FOREWARD.

STUDY CONTRIBUTORS

vii

ABSTRACT

1.0 INTRODUCTION

1.1

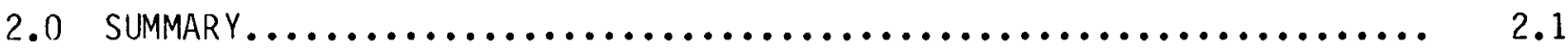

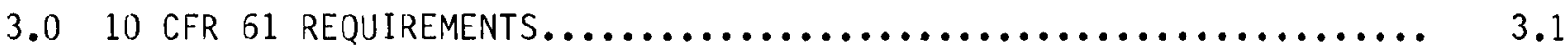

4.0 ALTERNATIVES FOR DECOMMISSIONING THE REFERENCE BWR ........... 4.1

4.1 THE REFERENCE BWR............................... 4.1

4.2 DECOMMISSIONING ALTERNATIVES $\ldots \ldots \ldots \ldots \ldots \ldots \ldots \ldots \ldots \ldots \ldots \ldots \ldots \ldots$

5.0 CHARACTERIZATION OF BWR DECOMMISSIONING WASTES $\ldots \ldots \ldots \ldots \ldots \ldots \ldots \ldots . . \ldots$

5.1 NEUTRON-ACTIVATED MATERIALS..................... 5.1

5.2 CONTAMINATEd MATERIALS......................... 5.1

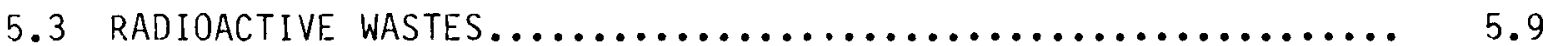

6.0 CLASSIFICATION OF BWR DECOMMISSIONING WASTES $\ldots \ldots \ldots \ldots \ldots \ldots \ldots \ldots \ldots$

6.1 NEUTRON-ACTIVATED MATERIALS $\ldots \ldots \ldots \ldots \ldots \ldots \ldots \ldots \ldots \ldots \ldots \ldots \ldots \ldots \ldots$

6.2 CONTAMINATED MATERIALS $\ldots \ldots \ldots \ldots \ldots \ldots \ldots \ldots \ldots \ldots \ldots \ldots \ldots \ldots \ldots \ldots$

6.3 RADIOACTIVE WASTES................................. 6.8

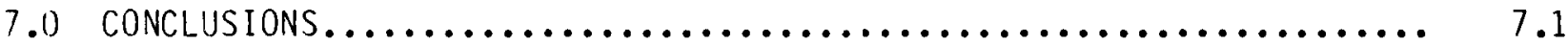

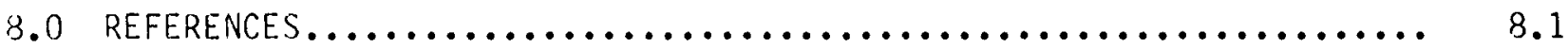



2.1 Waste Classes of Radioactive Wastes from BWR Decommissioning....... 2.3

3.1 Limiting Concentrations of Long-Lived Radionuclides Used as

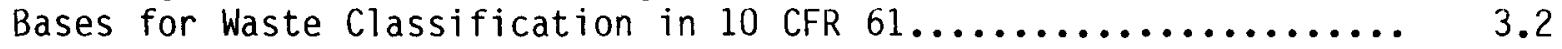

3.2 Limiting Concentrations of Short-Lived Radionuclides Used as

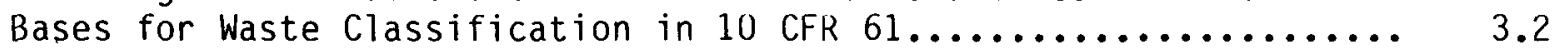

5.1 Neutron-Activated Materials from DECON at the Reference BWR...... 5.2

5.2 Neutron-Activated Materials from 30-Year Deferred Decontamination at the Reference BWR...................... 5.3

5.3 Neutron-Activated Materials from 50-Year Deferred Decontamination at the Reference BWR..................... 5.4

5.4 Neutron-Activated Materials from 100-Year Deferred Decontamination at the Reference BWR.................... 5.5

5.5 Neutron-Activated Materials from ENTOMB at the Reference BWR...... 5.6

5.6 Contaminated Materials from DECON at the Reference BWR.......... 5.8

5.7 Burial Volumes for Contaminated Materials from BWR Decommissioning..................................... 5.9

5.8 Contaminated Materials from ENTOMB at the Reference BWR......... 5.9

5.9 Radioactive Wastes from Decommissioning at the Reference BWR..... 5.10

6.1 Classification of Radioactive Wastes from BWR Decommissioning..... 6.2

6.2 Waste Classifications of Neutron-Activated Materials from DECON at the Reference BWR.......................... 6.3

6:3 Waste Classifications of Neutron-Activated Materials from 30-Year Deferred Decontamination at the Reference BWR........... 6.4

6.4 Waste Classifications of Neutron-Activated Materials from 50-Year Deferred Decontamination at the Reference BWR............ 6.5

6.5 Waste Classifications of Neutron-Activated Materials from 100-Year Deferred Decontamination at the Reference BWR........... 6.6

6.6 Waste Classifications of Neutron-Activated Materials from ENTOMB at the Reference BWR............................ 6.7 
6.7 Waste Classifications of Contaminated Materials from DECON at the Reference BWR.................................. 6.9

6.8 Waste Classifications of Radioactive Wastes from Decommissioning at the Reference BWR. 


\subsection{INTRODUCTION}

In the analysis of the decommissioning of the reference boiling water reactor power station (BWR) reported previously in NUREG/CR-0672, (1) it was assumed that all of the low-level radioactive waste from decommissioning could be disposed of by 1 and disposal at licensed shallow-land burial grounds. The purpose of this addendum is to examine this assumption of waste suitability for shallow-land burial by classifying the decommissioning wastes from the reference BWR study in terms of waste classes defined in Title 10, Part 61 of the Code of Federal Regulations (10 CFR 61). This information is intended for use by the Nuclear Regulatory Commission (NRC) as background data and bases in the modification of existing regulations and the development of new regulations pertaining to decommissioning activities. This report should also be helpful to operators of nuclear power plants in estimating decommissioning waste management costs and to burial ground operators in planning for the land burial of decommissioning wastes.

By Federal Register notice dated December 27, 1982, (2) the NRC promulgated a new regulation (10 CFR 61) governing the land disposal of low-level radioactive waste (LLW). This new regulation establishes three classes of LLW based on radiological hazard, and provides minimum and stability waste form requirements and near-surface disposal requirements for the land burial of these wastes. Wastes with radionuclide concentrations that do not meet the classification criteria of 10 CFR 61 are generally unacceptable for routine nearsurface disposal. Licensees are required to safely store these wastes until a specific determination can be made on their disposition.

The principal results of this analysis of classification of decommissioning wastes from the reference BWR are summarized in Section 2. A summary of waste classification requirements from 10 CFR 61 is given in Section 3 . The decommissioning alternatives evaluated in the reference BWR study are briefly summarized in Section 4. Information on quantities and radionuclide contents of the radioactive wastes from decommissioning the reference BWR is presented in Section 5. The classification of these wastes in terms of the waste classes defined in 10 CFR 61 is presented in Section 6. Conclusions and recommendations are given in Section 7. 


\subsection{SUMMARY}

In the analysis of the decommissioning of a reference boiling water reactor (BWR) reported previously in NUREG/CR-0672, it was assumed that the lowlevel radioactive wastes from decommissioning could be disposed of by nearsurface burial at a licensed shallow-land burial ground. The purpose of this addendum is to reevaluate this assumption in terms of the recently established requirements for waste characterization published in Title 10, Part 61 of the Code of Federal Regulations (10 CFR 61). To accomplish this reevaluation, radioactive wastes from the conceptual decommissioning of the reference BWR are classified in terms of the waste classes specified in Section 61.55 of 10 CFR. Section 61.55 establishes three classes of low-level radioactive waste ( $L L W$ ) based on radiological hazard, and defines limiting concentrations of long-lived and short-lived nuclides for each waste class. Minimum waste form and stability requirements are also defined for each waste class.

Class $A$ waste has the lowest concentrations of radioactivity and must meet minimum requirements for burial designed to facilitate handling at the disposal site and provide protection of the health and safety of burial site personnel. Class $B$ waste has higher concentrations of radioactivity and must meet more rigorous requirements on waste form to ensure stability after disposal. Class $C$ waste must not only meet more rigorous requirements on waste form to ensure stability, but also requires additional measures at the disposal facility to protect against inadvertent intrusion. Wastes with radionuclide concentrations that do not meet the classification criteria of 10 CFR 61 are generally unacceptable for routine near-surface disposal and must be safely stored by the licensee until a specific determination can be made on their disposition.

Radioactive materials that require disposal as a consequence of conceptual decommissioning of the reference BWR include 1) neutron-activated materials, 2) contaminated materials, and 3 ) radioactive wastes.

Neutron-activated materials include the reactor pressure vessel, vessel internal components and structures, and the surrounding concrete sacrificial shield located inside the primary containment. Significant amounts of the radioisotopes ${ }^{59} \mathrm{Ni}, 63 \mathrm{Ni}$, and ${ }^{94} \mathrm{Nb}$ are present in neutron-activated decommissioning wastes. The presence of these isotopes can affect the waste classification of neutron-activated material and could result in these wastes being unsuitable for shallow-land disposal.

Contaminated materials from BWR decommissioning include nearly all of the piping and equipment in the reactor building/primary containment, turbine generator building, and radwaste and control building, as well as many of the concrete surfaces of these buildings. There are no significant quantities of 
limiting long-lived isotopes in contaminated materials. The principal limiting short-lived isotopes in these materials are ${ }^{60} \mathrm{Co}$ and ${ }^{137} \mathrm{Cs}$. Average concentrations of limiting short-lived radionuclides in contaminated materials are low enough that, in general, contaminated materials constitute Class A waste.

Radioactive wastes from reactor decommissioning operations include both wet solid wastes and dry solid wastes. Wet solid wastes are the solidified wastes that result from the processing of chemical decontamination solutions and contaminated water volumes. Dry solid wastes include discarded contaminated materials such as rags and wipes, plastic sheeting, contaminated tools, and anti-contamination clothing. There are no significant quantities of limiting long-lived isotopes in either wet solid or dry solid radioactive wastes. The principal limiting short-lived isotopes in the waste are ${ }^{60} \mathrm{Co}$ and ${ }^{137} \mathrm{Cs}$. Most of the radioactive waste from decommissioning operations can be classified as Class A waste, with less than $25 \%$ (by volume) being classified as Class B waste.

The alternative approaches to decommissioning a nuclear power station considered in the reference BWR study are DECON (immediate decontamination to unrestricted release), SAFSTOR (safe storage with deferred decontamination to unrestricted release), and ENTOMB (entombment of radioactive materials with decay to unrestricted release). The DECON alternative results in a greater quantity of radioactive waste being generated, and requires a greater commitment of disposal site space than either of the other two decommissioning alternatives. The nuclear waste generated during SAFSTOR operations includes radioactive waste from preparations for safe storage and waste generated during deferred decontamination. For safe storage periods of 50 years or longer, because of radioactive decay, the total waste from all SAFSTOR operations is significantly less than the waste volume generated during DECON. In the ENTOMB scenario analyzed in the reference BWR study, the long-lived reactor vessel internals are removed and shipped to a licensed burial site prior to entombment. The nuclear wastes resulting from ENTOMB operations include these longlived reactor components, any contaminated material not accommodated within the confines of the entombment structure, and radioactive wastes resulting from ENTOMB activities. The total waste volume generated for offsite disposal in this alternative is substantially less than that generated for DECON.

A summary of the classification requirements for the radioactive wastes from conceptual decommissioning of the reference BWR is given in Table 2.1. Data used to define the burial volumes and radionuclide concentrations that form the bases for the waste classification results are from Reference 1. While the total nuclear waste volume varies by more than a factor of 10 , depending on the decommissioning alternative, the volumes of Class $B$ and $C l a s s$ $C$ waste, and of waste that exceeds the Class $C$ limits, are essentially independent of the decommissioning alternative. 
TABLE 2.1. Waste Classes of Radioactive Wastes from BWR Decommissioning

\begin{tabular}{|c|c|c|c|c|c|c|c|c|c|}
\hline \multirow[b]{3}{*}{$\begin{array}{c}\text { Decommissioning } \\
\text { Alternative }\end{array}$} & \multirow{3}{*}{$\begin{array}{c}\text { Burial } \\
\text { Volume } \\
(a) \\
\left(m^{3}\right)\end{array}$} & \multicolumn{8}{|c|}{ Waste Class Assignment (b) } \\
\hline & & \multicolumn{2}{|c|}{ Class $A$} & \multicolumn{2}{|c|}{ Class $B$} & \multicolumn{2}{|c|}{ Class C } & \multicolumn{2}{|c|}{$\begin{array}{c}\text { Exceeds Class C } \\
\text { Limits }\end{array}$} \\
\hline & & $\begin{array}{c}\text { Vol ume } \\
\left(\mathrm{m}^{3}\right)\end{array}$ & Percent & $\begin{array}{l}\text { Vol ume } \\
\left(\mathrm{m}^{3}\right)\end{array}$ & Percent & $\begin{array}{l}\text { Volume } \\
\left(\mathrm{m}^{3}\right)\end{array}$ & Percent & $\begin{array}{c}\text { Volume } \\
\left(\mathrm{m}^{3}\right)\end{array}$ & Percent \\
\hline DECON & 18949 & 18476 & 97.5 & 373 & 2.0 & 53 & 0.3 & 47 & 0.2 \\
\hline $30-Y r$ SAFSTOR $(c)$ & 18949 & 18616 & 98.2 & 233 & 1.3 & 53 & 0.3 & 47 & 0.2 \\
\hline $50-Y r \quad \operatorname{SAFSTOR}(c)$ & 1783 & 1450 & 81.3 & 247 & 13.8 & 39 & 2.2 & 47 & 2.7 \\
\hline $100-Y_{r} \operatorname{SAFSTOR}^{(c)}$ & 1673 & 1340 & 80.1 & 247 & 14.8 & 39 & 2.3 & 47 & 2.8 \\
\hline ENTOMB & 8042 & 7569 & 94.1 & 373 & 4.6 & 53 & 0.7 & 47 & 0.6 \\
\hline
\end{tabular}

(a) Data on burial volumes for decommissioning wastes are from Sections H.5, I.3, J.5, J.7, and K.3 of Reference 1.

(b) Based on limiting concentrations of long- and short-lived radionuclides given in Table 1 and Table 2 of 10 CFR 61.55 .

(c) Includes radioactive wastes from both preparations for safe storage and deferred decontamination.

Most of the radioactive waste from BWR decommissioning ( $80 \%$ to $98 \%$, depending on the decommissioning alternative and the volume of waste generated for disposal) can be classified as Class A waste. To be acceptable for shallow-land disposal, this waste must meet the minimum packaging and waste form requirements given in 10 CFR $61.56(a)$.

A relatively small amount of the nuclear waste from BWR decommissioning is classified as Class B waste. This waste includes some neutron-activated stainless steel components with significant amounts of $63 \mathrm{Ni}$, solidified concentrator bottoms with high specific activity, and a fraction of the dry solid waste generated during decommissioning operations. Class B wastes must meet the stability requirements of 10 CFR $61.56(\mathrm{~b})$ that are intended to provide protection against structural degradation following burial. Most of the Class $B$ waste from BWR decommissioning would meet these structural stability requirements without additional processing.

Approximately $53 \mathrm{~m}^{3}$ of the waste from DECON, 30-year SAFSTOR, and ENTOMB, and approximately $39 \mathrm{~m}^{3}$ of the waste from 50-year SAFSTOR and 100-year SAFSTOR is estimated to be Class $C$ waste. This waste consists of neutron-activated stainless steel reactor vessel internals with high concentrations of $63_{\mathrm{Ni}}$ and ${ }^{94} \mathrm{Nb}$. Class $\mathrm{C}$ waste must meet the stability requirements of $10 \mathrm{CFR} 61.56(\mathrm{~b})$ and must also be disposed of by the burial site operator using methods that provide additional protection against inadvertent intrusion into the burial ground for at least 500 years. Hence, the disposal costs for Class C waste would probably be significantly higher than the disposal costs for Class $A$ and Class $B$ wastes. In this addendum, no attempt is made to estimate these additional costs. 
The neutron-activated stainless steel core shroud (burial volume $47 \mathrm{~m}^{3}$ ) has such high concentrations of ${ }^{59} \mathrm{Ni},{ }^{63} \mathrm{Ni}$, and ${ }^{94} \mathrm{Nb}$ that it exceeds the Class C limits of 10 CFR 61. This material is therefore generally unacceptable for routine near-surface disposal. The licensee is required to safely store this waste until a specific determination can be made on its disposition. 


\section{$3.0 \quad 10$ CFR 61 REQUIREMENTS}

By Federal Register Notice dated December 27, 1982, (2) the NRC amended its regulations to provide specific requirements for licensing the land disposal of low-level radioactive wastes containing source, special nuclear, or byproduct material. The majority of these requirements are contained in a new Part 61 to Title 10 of the Code of Federal Regulations (10 CFR 61), "Licensing Requirements for Land Disposal of Radioactive Wastes," which took effect on January 23, 1983. Some additional requirements directed primarily at waste generators and handlers were concurrently published as a new Section 20.311 of Part 20, "Standards for Protection Against Radiation." The effective date of 10 CFR 20.311 is December 27, 1983.

Although the new requirements apply primarily to disposal site operators, they also include provisions that pertain to persons who generate waste that will be disposed of at land disposal facilities. Licensees generating waste have a responsibility to determine the presence and concentrations of various nuclides listed in Section 61.55, and thereby to classify the waste. Packaging and waste stability requirements for waste destined for shallow-land burial depend on the waste classification. Wastes that do not meet the classification requirements of Section 61.55 require special provisions for their disposal and would, in most instances, require interim storage pending identification of a suitable disposal alternative.

Section 61.55 defines radioactive waste suitable for land disposal as falling into one of three categories, i.e., Class A waste, Class B waste, and Class $C$ waste. Wastes are determined to fall into one of these classes by comparison to limiting concentrations of particular long-lived and short-lived radionuclides. Class $A$ waste contains the lowest radionuclide concentrations and must meet only minimum waste form requirements. Class B and C wastes contain higher radionuclide concentrations and must meet both the minimum waste form and the stability requirements of Section 61.56. Class C waste must be disposed of by use of methods that provide added protection against inadvertent intrusion into the burial ground.

The basis for classification of LLW in terms of long-lived radionuclide concentrations is shown in Table 3.1, reproduced from Table 1 of 10 CFR 61.55 . The basis for classification of LLW in terms of short-lived radionuclide concentrations is shown in Table 3.2, reproduced from Table 2 of 10 CFR 61.55 .

If the radioactive waste contains only radionuclides listed in Table 3.1 (long-lived radionuclides), classification is determined using the following guidelines. If the concentration does not exceed 0.1 times the value in the table, the waste is Class $A$. If the concentration exceeds 0.1 times the value in Table 3.1 but does not exceed the value in the table, the waste is Class $C$. 
TABLE 3.1. Limiting Concentrations of Long-Lived Radionuc]ides Used as Bases for Waste Classification in 10 CFR 61 (a)

\begin{tabular}{lc} 
Radionuclide & $\begin{array}{c}\text { Concentration } \\
\text { (curies } / \mathrm{m}^{3} \text { ) }\end{array}$ \\
\cline { 1 - 2 }${ }^{14} \mathrm{C}$ & 8 \\
${ }^{14} \mathrm{C}$ in activated metal & 80 \\
${ }^{59} \mathrm{Ni}$ in activated metal & 220 \\
${ }^{94} \mathrm{Nb}$ in activated metal & 0.2 \\
${ }^{99} \mathrm{TC}$ & 3 \\
$129 \mathrm{I}$ & 0.08 \\
Alpha-emitting transuranic nuclides & $100(\mathrm{~b})$ \\
with half-life greater than five years & \\
$241_{\mathrm{Pu}}$ & $3500(\mathrm{~b})$ \\
$242 \mathrm{Cm}$ & $20000^{(\mathrm{b})}$
\end{tabular}

(a) Reproduced from Table 1 of 10 CFR 61.55 .

(b) Units are nanocuries per gram.

TABLE 3.2. Limiting Concentrations of Short-Lived Radionuclides Used as Bases for Waste Classification in $10 \mathrm{CFR} 61$ (a)

Radionuclides

Total of all nuclides with half-

life less than five years

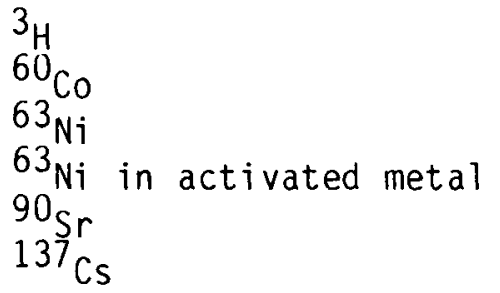

$\frac{\text { Concentration (curies/m } \mathrm{m}^{3} \text { ) }}{\frac{\text { Column 1 }}{700}} \frac{\text { Column 2 }}{\text { (b) }} \frac{\text { Column } 3}{\text { (b) }}$

40

700

3.5

35

(b)

(b)

70

700

150

0.04

1 (b)

7000

7000

4600

(a) Reproduced from Table 2 of 10 CFR 6l.55.

(b) There are no limits established for these radionuclides in Class $B$ or $C$ waste. Practical considerations such as the effects of external radiation and internal heat generation on transportation, handling, and disposal will limit the concentrations for these wastes. These wastes shall be Class $B$ unless the concentrations of other nuclides in Table 3.2 determine the waste to be $C$ lass $C$ independent of these nuclides. 
If the concentration exceeds the value in Table 3.1, the waste is generally unacceptable for near-surface disposal. For example, for Class A waste the limiting concentration of long-lived alpha-emitting transuranic nuclides is 10 $\mathrm{nCi} / \mathrm{gram}$. For Class $\mathrm{C}$ waste, the disposal limit for transuranic waste is set at $100 \mathrm{nCi} / \mathrm{gram}$.

If the radioactive waste contains only radionuclides listed in Table 3.2 (short-lived radionuclides), classification is determined using the following guidelines. If the concentration does not exceed the value in Column 1, the waste is Class $A$. If the concentration exceeds the value in Column 1 , but does not exceed the value in Column 2 , the waste is class $B$. If the concentration exceeds the value in Column 2 but does not exceed the value in Column 3 , the waste is class $C$. If the concentration exceeds the value in Column 3 , the waste is generally unacceptable for near-surface disposal.

If radioactive waste does not contain any of the radionuclides in either Table 3.1 or Table 3.2 , it is Class A.

If radioactive waste contains a mixture of both long-lived and short-lived nuclides, some of which are listed in Table 3.1 and some in Table 3.2 , the waste classification is determined in the following manner. If the concentration of a nuclide listed in Table 3.1 does not exceed 0.1 times the value given in Table 3.1, the class is determined by the concentration of nuclides listed in Table 3.2. If the concentration of a nuclide listed in Table 3.1 exceeds 0.1 times the value listed in Table 3.1 but does not exceed the value in Table 3.1 , the waste is $\mathrm{Class} C$, provided the concentration of nuclides listed in Table 3.2 does not exceed the values shown in Column 3 of Table 3.2 .

For determining the classification of waste that contains a mixture of radionuclides, the sum-of-fractions rule described in 10 CFR $61.55(a)(7)$ is used. To use the sum-of-fractions rule, it is necessary to divide each nuclide's concentration by the appropriate limit and add the resulting values. The appropriate limits must all be taken from the same column of the same table. The sum of the fractions for the column must be less than 1.0 if the waste class is to be determined by that column.

The NRC has prepared a technical position $(3)$ describing procedures acceptable to the regulatory staff which may be used by licensees to determine the presence and concentrations of radionuclides listed in Table 3.1 and Table 3.2 , thereby classifying wastes for near-surface disposal. The basic methods for identifying radionuclide concentrations in nuclear waste include the following:

- materials accountability

- classification by source

- gross radioactivity measurements

- direct measurement of individual radionuclides. 
Materials accountability refers to the process whereby a given quantity (and resulting concentration) of radioactive material may be known to be contained within a given waste, or may be inferred by determining the difference between the quantities of radioactive material entering and exiting a particular process. Classification by source is similar to materials accountability and involves determining the radionuclide content and classification of waste through knowledge and control of its source. Gross radioactivity measurement entails the establishment of a program to correlate specific radionuclide concentrations in the waste with gross measurements of radioactivity levels. Radionuclide concentrations may also be measured directly or may be inferred by ratioing to concentrations of radioisotopes that can be readily measured.

The NRC technical position (3) also provides guidance on determining the waste volumes to be used in calculating radionuclide concentrations. In many cases the volume used for waste classification purposes may be taken to be the volume of the waste container. This would be true of trash waste streams compacted into shipping containers. If a particular waste is stabilized within a waste container using a solidification medium such as cement or bitumen, the classification volume may be considered to be the volume of the solidified mass. The waste classification volume of large unpackaged components such as contaminated pumps, heat exchangers, etc., may be taken to be the overall volume of the component.

If the volume of the waste container is significantly larger (i.e., more than $10 \%$ larger) then the volume of the contaminated waste, the volume used for classification purposes should be that of the waste. For example, for wastes such as ion exchange resins or filter media contained within a disposable demineralizer or liner, the volume used for waste classification should be the volume of the contained waste rather than the gross volume of the container. For neutron-activated materials such as the reactor pressure vessel or the vessel internals that are cut into sections and packaged for disposal, the volume for waste classification should be the full-density volume of the material (i.e., the weight divided by the density) rather than the container volume.

Section 10 CFR 61.55 (a)(8) states that in deterinining radionuclide concentrations in nuclear waste, the concentrations may be averaged over the volume of the waste, or over the weight if the concentration units are expressed in nanocuries per gram. In the averaging process, consideration should be given to 1) whether the distribution of radionuclides within the waste can be considered to be reasonably homogeneous, and 2) whether the volume of the waste container is significantly larger than the volume of the waste itself and the differential volume consists largely of void space. Most waste forms may be considered homogeneous for purposes of waste classification. Examples of homogeneous wastes include spent ion exchange resins, filter media, solidified liquids, contaminated dirt, contaminated concrete, and contaminated trash when compacted in waste containers. 


\subsection{ALTERNATIVES FOR DECOMMISSIONING THE REFERENCE BWR}

The quantities and curie contents of the radioactive wastes from lightwater reactor decominissioning depend on several factors, including the reactor operating history, decontamination activities performed during the operating life, and the alternative chosen for decommissioning of the reactor. Three decommissioning alternatives, DECON, SAFSTOR, and ENTOMB, are analyzed in the reference study of BWR decommissioning. These alternatives are briefly described in this section. The characteristics of the radioactive wastes that result when each alternative is conceptually applied to the decommissioning of the reference BWR are summarized in Section 5.

\subsection{THE REFERENCE BWR}

The reference BWR is a 1155 MWe (3320-MWt) reactor bein's built by the Washington Public Power Supply System; it is designated as the WPPSS Nuclear Project No. 2 and is located near Richland, Washington. The nuclear steam supply system is a direct-cycle boiling water reactor of Mark-II containment design manufactured by the General Electric Company, and is generally representative of the current generation of large BWRs. Descriptive information about the reference $p l a n t$ is presented in Chapter 7 and Appendix $C$ of Reference 1.

\subsection{DECOMMISSIONING ALTERNATIVES}

The alternative approaches to decommissioning a nuclear power station that are considered in the reference BWR study are OECON (immediate decontamination to unrestricted release), SAFSTOR (safe storage with deferred decontamination to unrestricted release), and ENTOMB (entombment of radioactive materials with

decay to unrestricted release. $)(4,5)$ These alternatives can be defined as follows.

DECON is the prompt removal from the facility and site of all materials with residual radioactivity levels greater than those permitted for unrestricted use of the property. DECON meets the requirements for termination of the facility license and, under present regulatory requirements, is the only decommissioning alternative that renders the facility and site available for unrestricted use within a short time period. DECON requires the removal of all equipment, structures, and site materials that are radioactively activated or contaminated to levels greater than acceptable residual contamination levels. This alternative results in a greater quantity of radioactive waste being generated for offsite disposal and requires a greater commitment of disposal site space than either of the other two decommissioning alternatives. 
SAFSTOR comprises those activities required to prepare and maintain the facility in a condition that poses an acceptable risk to the public and safely stores the property for a period to allow some decay of the onsite radioactivity, followed by decontamination of the facility to an unrestricted level. SAFSTOR includes three phases of activity: 1) preparations for safe storage, 2) safe storage, and 3) deferred decontamination. Preparations for safe storage include comprehensive cleanup and decontamination activities sufficient to allow shutdown of all plant systems and installation of security barriers and remotely monitored surveillance devices. Preparations for safe storage are followed by a period of continuing care (safe storage) to permit some decay of the residual radioactivity. Requirements during the continuing-care period include activities to maintain the structural integrity and prevent intrusion into the facility. Since materials having radioactivity levels above unrestricted release levels are still onsite, an amended nuclear license remains in force until the deferred decontamination is complete. At the conclusion of the safe storage period, deferred decontamination is accomplished to remove from the site any materials with residual radioactivity greater than that permitted for release of the property for unrestricted use. In the reference study, decommissioning requirements for continuing-care periods of 30, 50, and 100 years are analyzed. For continuing-care periods of 50 years or longer, because of radioactive decay, the total for the volume of nuclear waste generated during deferred decontamination plus the waste volume generated during preparations for safe storage is significantly less than the waste volume generated during DECON.

ENTOMB is the encasement and maintenance of nonreleasable radioactive materials in a monolithic structure of concrete or other structural material with long-term surveillance until the radioactivity has decayed to levels suitable for unrestricted use. The structure should be sufficiently strong and long-lived to ensure retention of the radionuclides during the long-term surveillance period. In the reference BWR study, the entombment structure is the steel primary containment vessel enclosed within the concrete biological shield.

Two approaches to ENTOMB at a BWR are possible: 1) the reactor vessel internals, which have extremely long-lived radioactivity, are removed and shipped to a nuclear waste repository; and 2) the reactor vessel internals are left in place. In each case, as much of the contaminated equipment from outside the entombment structure as can be stored in the entombment structure is moved there. In the first case, because of the relatively short half-lives of the entombed radioactivity, it may be possible, without dismantiing the structure, to terminate the amended nuclear license and release the structure for unrestricted use after a period of about 100 years. In the second case, existing regulations require the amended nuclear license to remain in force for an indefinite period. 
The entombment scenario analyzed in the reference BWR study is the first approach, in which the long-lived reactor vessel internals are removed prior to entombment. The nuclear wastes generated for disposal include these long-lived reactor components, any contaminated material not accommodated within the confines of the entombment structure, and radioactive wastes resulting from ENTOMB activities. The total waste volume generated for offsite disposal in this alternative is substantially less than that generated for DECON. 


\subsection{CHARACTERIZATION OF BWR DECOMMISSIONING WASTES}

The radioactive materials that require disposal as a consequence of lightwater reactor decommissioning operations include 1) neutron-activated materials, 2) contaminated materials, and 3) radioactive wastes. Information on waste volumes, curie contents, and major radionuclides in the wastes from decommissioning the reference BWR is given in Reference 1. Waste characterization data from Reference 1 are summarized in this section to provide a basis for the waste classification discussion of Section 6.0.

\subsection{NEUTRON-ACTIVATED MATERIALS}

All of the neutron-activated materials from BWR decommissioning are contained in the reactor pressure vessel, vessel internal components and structures, and the surrounding concrete sacrificial shield located inside the primary containment. Tables 5.1 through 5.5 summarize data on volumes, radioactivity (curie) contents, and fractional radioactivity of limiting long-and short-lived radionuclides for neutron-activated materials. Table 5.1 shows data on neutron-activated wastes from DECON at the reference BWR. Tables 5.2 through 5.4 show data on neutron-activated wastes from deferred decontamination after shutdown periods of 30,50 and 100 years. Table 5.5 shows data on neutron-activated wastes from ENTOMB. Burial volumes and curie contents are taken from Table I.3-3 of Reference 1. Full-density volumes are calculated by dividing the mass by the density where the mass is from Table I.3-3 of Reference 1. The radioactivities of activated components from deferred decontamination are corrected for decay on the basis of radionuclide inventory data presented in Tables E.1-1, E.1-2 and E.1-3 of Reference 1. These tables are also the source of the data on fractional radioactivity of the limiting radionuclides. Limiting radionuclides are those nuclides whose concentrations in the waste provide the bases for the classification of the radioactive wastes for burial (see Tables 3.1 and 3.2 of this addendum).

An important characteristic of the neutron-activated material from BWR decommissioning is the presence of the radioisotopes, ${ }^{59} \mathrm{Ni}, 6{ }^{6 \mathrm{Ni}}$, and ${ }^{94} \mathrm{Nb}$. As shown in Tables 3.1 and 3.2 , these isotopes can affect the waste classification of the material. If significant amounts of these isotopes are present, the material may be Class B or Class $C$ or may exceed the Class C limits.

\subsection{CONTAMINATED MATERIALS}

Contaminated materials from BWR decommissioning include nearly all of the piping and equipment in the reactor building/primary containment, turbinegenerator building, and radwaste and control building. In addition, many of 
TARLE 5.1. Neutron-Activated Materials from DECON at the Reference BWR

\begin{tabular}{|c|c|c|c|c|c|c|c|c|c|c|c|c|}
\hline \multirow[b]{2}{*}{ Reactor Component } & \multirow[b]{2}{*}{ Material } & \multirow[b]{2}{*}{$\begin{array}{c}\text { Radioactiyity } \\
\text { (Ci) (a) }\end{array}$} & \multirow[b]{2}{*}{$\begin{array}{l}\text { Burial } \\
\text { Volume } \\
\left(m^{3}\right)^{(a)}\end{array}$} & \multirow[b]{2}{*}{$\begin{array}{l}\text { Full-tensity } \\
\text { Volume } \\
\quad\left(\mathrm{m}^{3}\right)\end{array}$} & \multirow[b]{2}{*}{$\mathrm{Ci} / \mathrm{m}^{3(c)}$} & \multicolumn{4}{|c|}{$\begin{array}{l}\text { Fractional Radionactivity } \\
\text { of Linniting Lingy } \\
\text { Lived Naclides }\end{array}$} & \multicolumn{3}{|c|}{$\begin{array}{l}\text { Fractional Radionactivity } \\
\text { of Limiting Short- } \\
\text { Lived Macl ides }\end{array}$} \\
\hline & & & & & & ${ }^{14} \mathrm{C}$ & $59 \mathrm{Ni}$ & ${ }^{94} \mathrm{~B}$ & ${ }^{99} \mathrm{Ic}$ & ${ }^{60} \mathrm{C}_{0}$ & ${ }^{63} \mathrm{Ni}$ & $\begin{array}{l}\text { Less than } \\
\text { 5-Year } \\
\text { Half-Life }\end{array}$ \\
\hline Stean Separator Assenbly & $\overline{\text { Stainless Steel }}$ & 9600 & 10 & 1.2 & 8000 & $3.7 \times 10^{-5}$ & $2.2 \times 10^{-4}$ & $5.3 \times 10^{-7}$ & $1.1 \times 10^{-8}$ & $1.2 \times 10^{-1}$ & $3.1 \times 10^{-2}$ & $8.5 \times 10^{-1}$ \\
\hline Fuel Support Pieces & Stainless Steel & 700 & 5 & 0.7 & 1000 & $3.7 \times 10^{-5}$ & $2.2 \times 10^{-4}$ & $5.3 \times 10^{7}$ & $1.1 \times 10^{8}$ & $1.2 \times 10^{-1}$ & $3.1 \times 10^{-2}$ & $8.5 \times 10^{-1}$ \\
\hline Control Rods \& In-Core Instruments & Stainless Steel & 189000 & 15 & 2.5 & 75600 & $3.7 \times 10^{-5}$ & $2.2 \times 10^{-4}$ & $5.3 \times 10^{-7}$ & $1.1 \times 10^{-8}$ & $1.2 \times 10^{-1}$ & $3.1 \times 10^{-2}$ & $8.5 \times 10^{-1}$ \\
\hline Control Rod Guide Tubes & Stainless Steel & 100 & 4 & 0.5 & 200 & $3.7 \times 10^{-5}$ & $2.2 \times 10^{-4}$ & $5.3 \times 10^{-7}$ & $1.1 \times 10^{-8}$ & $1.2 \times 10^{-1}$ & $3.1 \times 10^{-2}$ & $8.5 \times 10^{-1}$ \\
\hline Jet Pamp Assenblies & Stainless Steel & 20000 & 14 & 0.8 & 25000 & $3.7 \times 10^{-5}$ & $2.2 \times 10^{-4}$ & $5.3 \times 10^{-7}$ & $1.1 \times 10^{-8}$ & $1.2 \times 10^{-1}$ & $3.1 \times 10^{-2}$ & $8.5 \times 10^{-1}$ \\
\hline Top Fuel Guide & Stainless Steel & 30100 & 24 & 0.3 & 100000 & $3.7 \times 10^{-5}$ & $2.2 \times 10^{-4}$ & $5.3 \times 10^{-7}$ & $1.1 \times 10^{-8}$ & $1.2 \times 10^{-1}$ & $3.1 \times 10^{-2}$ & $8.5 \times 10^{-1}$ \\
\hline Core Support Plate & Stainless Steel & 650 & 11 & 2.4 & 271 & $3.7 \times 10^{-5}$ & $2.2 \times 10^{-4}$ & $5.3 \times 10^{-7}$ & $1.1 \times 10^{-8}$ & $1.2 \times 10^{-1}$ & $3.1 \times 10^{-2}$ & $8.5 \times 10^{-1}$ \\
\hline Core Shroud & Stainless Steel & 6300000 & 47 & 4.1 & 1537000 & $3.7 \times 10^{-5}$ & $2.2 \times 10^{-4}$ & $5.3 \times 10^{-7}$ & $1.1 \times 10^{-8}$ & $1.2 \times 10^{-1}$ & $3.1 \times 10^{-2}$ & $8.5 \times 10^{-1}$ \\
\hline Reactor Vessel wall & Carton Steel & 2160 & 8 & 21.6 & 100 & $1.8 \times 10^{-5}$ & $4.0 \times 10^{-5}$ & -- & $7.2 \times 10^{-7}$ & $1.8 \times 10^{-2}$ & $4.7 \times 10^{-3}$ & $9.8 \times 10^{-1}$ \\
\hline Sacrificial Shield & Concrete & 170 & 90 & 90.0 & 2 & $3.5 \times 10^{-5}$ & $3.2 \times 10^{-5}$ & -- & $1.1 \times 10^{-6}$ & $1.7 \times 10^{-2}$ & $3.8 \times 10^{-3}$ & $9.8 \times 10^{-1}$ \\
\hline Totals & & 6552480 & 228 & 124.1 & & & & & & & & \\
\hline
\end{tabular}

(a) Based on Table 1.3-3 of Refenence 1.

(b) Mass divided by density where nass is fram Table 1.3-3 of Reference 1.

(c) Radioactivity (Ci) divided by full-density volume.

(d) Based on Tables E.1-1, E.1-2, and E.1-3 of Reference 1. 
TABLE 5.2. Neutron-Activated Materials from 30-Year Deferred Decontamination at the Reference BWR

\begin{tabular}{|c|c|c|c|c|c|c|c|c|c|c|c|c|c|}
\hline & \multirow[b]{2}{*}{ Reactor Component } & \multirow[b]{2}{*}{ Material } & \multirow[b]{2}{*}{$\begin{array}{l}\text { Radioactiyity } \\
(\mathrm{Ci})^{(\mathrm{a})}\end{array}$} & \multirow[b]{2}{*}{$\begin{array}{l}\text { Burial } \\
\text { Volume } \\
\left(\mathrm{m}^{3}\right)^{(\mathrm{a})} \\
\end{array}$} & \multirow[b]{2}{*}{$\begin{array}{l}\text { Ful 1- Density } \\
\text { Volume } \\
\left(\mathrm{b}^{3}\right) \\
\end{array}$} & \multirow[b]{2}{*}{$\mathrm{Ci} / \mathrm{mm}^{3(c)}$} & \multicolumn{4}{|c|}{$\begin{array}{c}\text { Iractional Radioactivity } \\
\text { of Limiting I gng- } \\
\text { Lived Nr lides (d,e) }\end{array}$} & \multicolumn{3}{|c|}{$\begin{array}{c}\text { Fractional Radioactivity } \\
\text { of Liniting Short- } \\
\text { Lived Nuclides }(\mathrm{d}, \mathrm{e})\end{array}$} \\
\hline & & & & & & & ${ }^{14} \mathrm{C}$ & ${ }^{59} \mathrm{Ni}$ & ${ }^{94} \mathrm{~N}$ & ${ }^{99} \mathrm{TC}$ & ${ }^{60} \mathrm{Co}$ & $63_{\mathrm{Ni}}$ & $\begin{array}{l}\text { Less Than } \\
\text { 5-Ypar } \\
\text { Half Life }\end{array}$ \\
\hline & Stean Separator Assembly & Stainless Steel & 260 & 10 & 1.2 & 217 & $1.4 \times 10^{-3}$ & $8.2 \times 10^{-3}$ & $1.9 \times 10^{-5}$ & $4.1 \times 10^{-7}$ & $8.4 \times 10^{-2}$ & $9.0 \times 10^{-1}$ & $4.0 \times 10^{-3}$ \\
\hline & Fuel Support Pieces & Stainless Steel & 20 & 5 & 0.7 & 29 & $1.4 \times 10^{-3}$ & $8.2 \times 10^{-3}$ & $1.9 \times 10^{-5}$ & $4.1 \times 10^{-7}$ & $8.4 \times 10^{-2}$ & $9.0 \times 10^{-1}$ & $4.0 \times 10^{-3}$ \\
\hline & Control Rods \& In-Core Instruments & Stainless Steel & 5140 & 15 & 2.5 & 2060 & $1.4 \times 10^{-3}$ & $8.2 \times 10^{-3}$ & $1.9 \times 10^{-5}$ & $4.1 \times 10^{-7}$ & $8.4 \times 10^{-2}$ & $9.0 \times 10^{-1}$ & $4.0 \times 10^{-3}$ \\
\hline & Control Rod Guide Tibes & Stainless Steel & 3 & 4 & 0.5 & 6 & $1.4 \times 10^{-3}$ & $8.2 \times 10^{-3}$ & $1.9 \times 10^{-5}$ & $4.1 \times 10^{-7}$ & $8.4 \times 10^{-2}$ & $9.0 \times 10^{-1}$ & $4.0 \times 10^{-3}$ \\
\hline G & Jet. Punp Assemblies & Stainless Steel & 540 & 14 & 0.8 & 675 & $1.4 \times 10^{-3}$ & $8.2 \times 10^{-3}$ & $1.9 \times 10^{-5}$ & $4.1 \times 10^{-7}$ & $8.4 \times 10^{-2}$ & $9.0 \times 10^{-1}$ & $4.0 \times 10^{-3}$ \\
\hline$\omega$ & Top Fuel Guide & Stainless Steel & 820 & 24 & 0.3 & 2730 & $1.4 \times 10^{-3}$ & $8.2 \times 10^{-3}$ & $1.9 \times 10^{-5}$ & $4.1 \times 10^{-7}$ & $8.4 \times 10^{-2}$ & $9.0 \times 10^{-1}$ & $4.0 \times 10^{-3}$ \\
\hline & Core Support Plate & Stainless Steel & 20 & 11 & 2.4 & 8.3 & $1.4 \times 10^{-3}$ & $8.2 \times 10^{-3}$ & $1.9 \times 10^{-5}$ & $4.1 \times 10^{-7}$ & $8.4 \times 10^{-2}$ & $9.0 \times 10^{-1}$ & $4.0 \times 10^{-3}$ \\
\hline & Core Shroud & Stainless Steel & 171360 & 47 & 4.1 & 41800 & $1.4 \times 10^{-3}$ & $8.2 \times 10^{-3}$ & $1.9 \times 10^{-5}$ & $4.1 \times 10^{-7}$ & $8.4 \times 10^{-2}$ & $9.0 \times 10^{-1}$ & $4.0 \times 10^{-3}$ \\
\hline & Reactor Vessel Wall & Carbon Steel & 10 & 8 & 21.6 & 0.5 & $4.1 \times 10^{-3}$ & $8.9 \times 10^{-3}$ & - & $1.6 \times 10^{-4}$ & $7.7 \times 10^{-2}$ & $8.4 \times 10^{-1}$ & $6.9 \times 10^{-2}$ \\
\hline & Sacrificial Shield & Concrete & 1 & 90 & 90.0 & 0.01 & $5.8 \times 10^{-3}$ & $5.3 \times 10^{-3}$ & - & $1.7 \times 10^{-4}$ & $5.3 \times 10^{-2}$ & $5.0 \times 10^{-1}$ & $1.2 \times 10^{-1}$ \\
\hline & Totals & & 178174 & 278 & 124.1 & & & & & & & & \\
\hline
\end{tabular}

(a) Rased on Table 1.3-3 of Reference 1.

(b) Mass divided by density where mass is fran Table 1.3-3 of Refenence 1.

(c) Radioactivity (Ci) divided by full-density volume.

(d) Based on Tables E.1-1, E.1-2, and E.1-3 of Reference 1.

(e) Corrected for radioactive decay on the bases of radionuc.lide inventories in Tables E.1-1, E.1-2, and E.1-3 of Reference 1. 
TABLE 5.3. Neutron-Activated Materials from 50-Year Deferred Decontamination at the Reference BWR

\begin{tabular}{|c|c|c|c|c|c|c|c|c|c|c|c|c|}
\hline Reactor Component & Material & $\begin{array}{c}\text { Radioactiyity } \\
(\mathrm{Ci})(\mathrm{a})\end{array}$ & $\begin{array}{l}\text { Burial } \\
\text { Volume } \\
\left(\mathrm{Ii}^{3}\right)^{(2)}\end{array}$ & $\begin{array}{c}\text { Full-hensity } \\
\text { Volume }(b) \\
\left(\mathrm{m}^{3}\right) \\
\end{array}$ & $\mathrm{Ci} / \mathrm{m}^{3}(\mathrm{c})$ & \multicolumn{4}{|c|}{ 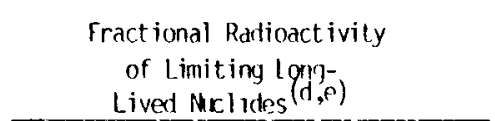 } & \multicolumn{3}{|c|}{$\begin{array}{l}\text { Fractional Radinactivity } \\
\text { of Limiting Short } \\
\text { Lived Nolides }(\mathrm{d}, \mathrm{e})\end{array}$} \\
\hline Fuel Support Pieces & Stainless Steel & 15 & 5 & 0.7 & 22 & $1.7 \times 10^{-3}$ & $1.0 \times 10^{-2}$. & $2.4 \times 10^{-5}$ & $5.2 \times 10^{-7}$ & $7.6 \times 10^{-3}$ & $9.8 \times 10^{-1}$ & $2.5 \times 10^{-5}$ \\
\hline Control Rods \& In-Core Instruments & Stainless Steel & 4060 & 15 & 2.5 & 1670 & $1.7 \times 10^{-3}$ & $1.0 \times 10^{-2}$ & $2.4 \times 10^{-5}$ & $5.2 \times 10^{-7}$ & $7.6 \times 10^{-3}$ & $9.8 \times 10^{-1}$ & $2.5 \times 10^{-5}$ \\
\hline Control Guide Tuses & Stainless Steel & 2 & 4 & 0.5 & 4 & $1.7 \times 10^{-3}$ & $1.0 \times 10^{-2}$ & $2.4 \times 10^{-5}$ & $5.2 \times 10^{-7}$ & $7.6 \times 10^{-3}$ & $9.8 \times 10^{-1}$ & $2.5 \times 10^{-5}$ \\
\hline Jet Pump Assentilies & Stainless Steel & 430 & 14 & 0.8 & 538 & $1.7 \times 10^{-3}$ & $1.0 \times 10^{-2}$ & $2.4 \times 10^{-5}$ & $5.2 \times 10^{-7}$ & $7.6 \times 10^{-3}$ & $9.8 \times 10^{-1}$ & $2.5 \times 10^{-5}$ \\
\hline Top Fuel Quide & Stainless Steel & 650 & 24 & 0.3 & 2170 & $1.7 \times 10^{-3}$ & $1.0 \times 10^{-2}$ & $2.4 \times 10^{-5}$ & $5.2 \times 10^{-7}$ & $7.6 \times 10^{-3}$ & $9.8 \times 10^{-1}$ & $2.5 \times 10^{-5}$ \\
\hline Core Support Plate & Stainless Steel & 15 & 11 & 2.4 & 6.2 & $1.7 \times 10^{-3}$ & $1.0 \times 10^{-2}$ & $2.4 \times 10^{-5}$ & $5.2 \times 10^{-7}$ & $7.6 \times 10^{-3}$ & $9.8 \times 10^{-1}$ & $2.5 \times 10^{-5}$ \\
\hline Core Shroud & Stainless Steel & 135450 & 47 & 4.1 & 33000 & $1.7 \times 10^{-3}$ & $1.0 \times 10^{-2}$ & $2.4 \times 10^{-5}$ & $5.2 \times 10^{-7}$ & $7.6 \times 10^{-3}$ & $9.8 \times 10^{-1}$ & $2.5 \times 10^{-5}$ \\
\hline Reactor Vessel wall & Carbon Steel & 10 & 8 & 21.6 & 0.5 & $5.5 \times 10^{-3}$ & $1.2 \times 10^{-2}$ & - & $2.2 \times 10^{-4}$ & $7.4 \times 10^{-3}$ & $9.7 \times 10^{-1}$ & $4.5 \times 10^{-4}$ \\
\hline Sacrificial Shield & Concrete & 1 & 90 & 90.0 & 0.01 & $7.6 \times 10^{-3}$ & $7.0 \times 10^{-3}$ & -. & $2.3 \times 10^{-4}$ & $5.0 \times 10^{-3}$ & $5.7 \times 10^{-1}$ & $3.1 \times 10^{-2}$ \\
\hline Totals & & 140843 & 228 & & & & & & & & & \\
\hline
\end{tabular}

\footnotetext{
(a) Based on Table I.3-3 of Reference 1.

(b) Mass divided by density were mass is fran Table 1.3-3 of Reference 1.

(c) Rarioactivity (Ci) divided by full-density volume.

(d) Based on Tables E.1-1, E.1-2, and E.1-3 of Reference 1.

(e) : Corrected for radioactive decay on the bases of radionuclide inventories in Tables E.1-1, E.1-2, and E.1-3 of Reference 1.
} 
TABLE 5.4. Neutron-Activated Materials from 100-Year Deferred Decontamination at the Reference BWR

\begin{tabular}{|c|c|c|c|c|c|c|c|c|c|c|c|c|}
\hline \multirow[b]{2}{*}{ Reactor Component } & \multirow[b]{2}{*}{ Material } & \multirow[b]{2}{*}{$\begin{array}{c}\text { Rad oactivity } \\
\left(\mathrm{C}_{1}\right)^{(\mathrm{a})} \\
\end{array}$} & \multirow[b]{2}{*}{$\begin{array}{l}\text { Burial } \\
\text { Volmee } \\
\left(\mathrm{m}^{3}\right)^{(a)} \\
\end{array}$} & \multirow[b]{2}{*}{$\begin{array}{c}\text { Full-Density } \\
\text { Volume }(b) \\
\left(\mathrm{m}^{3}\right) \\
\end{array}$} & \multirow[b]{2}{*}{$\mathrm{CI} / \mathrm{NI}^{3(\mathrm{c})}$} & \multicolumn{3}{|c|}{$\begin{array}{l}\text { Iractional Rodroactivity } \\
\text { of Limiting lony- } \\
\text { Lived Nel1 les }(\mathrm{d}, \mathrm{e})\end{array}$} & \multicolumn{4}{|c|}{$\begin{array}{l}\text { Fractional Radinactivity } \\
\text { of Limting Short- } \\
\text { Livexl Nol I ides (d,e) }\end{array}$} \\
\hline & & & & & & 14 & $\mathrm{SI}^{\mathrm{N}} \mathrm{N}$ & ${ }^{94} \mathrm{~N}$ & $-9+1 c$ & $500_{0}$ & $63_{\mathrm{NI}}$ & $\begin{array}{l}\text { Less Than } \\
5 \text {-Year } \\
\text { Half-Life }\end{array}$ \\
\hline Steam Separator Assentbly & Stainless Steel & 140 & 10 & 1.2 & 117 & $2.5 \times 10^{-3}$ & $1.5 \times 10^{-2}$ & $3.5 \times 10^{-5}$ & $7.6 \times 11^{-7}$ & $1.6 \times 10^{-5}$ & $9.8 \times 10^{-1}$ & -- \\
\hline Fuel Support Preces & Stainless Steel & 10 & 5 & 0.7 & 14 & $2.5 \times 10^{-3}$ & $1.5 \times 10^{-2}$ & $3.5 \times 10^{-5}$ & $7.6 \times 10^{-7}$ & $1.6 \times 10^{-5}$ & $9.8 \times 10^{-1}$ & - \\
\hline Control Rods \& In-Core Instruments & Stainless Steel & 2800 & 15 & 2.5 & 1120 & $2.5 \times 10^{-3}$ & $1.5 \times 10^{-2}$ & $3.5 \times 10^{-5}$ & $7.6 \times 10^{-7}$ & $1.6 \times 10^{-5}$ & $9.8 \times 10^{-1}$ & -- \\
\hline Control Gunde Tuhes & Starnless Steel & 2 & 4 & 0.5 & 4 & $2.5 \times 10^{-3}$ & $1.5 \times 10^{-2}$ & $3.5 \times 10^{-5}$ & $7.6 \times 10^{-7}$ & $1.6 \times 10^{-5}$ & $9.8 \times 10^{-1}$ & - \\
\hline Jet Pump Assembl ies & Starnless Steel & 300 & 14 & 0.8 & 375 & $2.5 \times 10^{-3}$ & $1.5 \times 10^{-2}$ & $3.5 \times 10^{-5}$ & $7.6 \times 10^{-7}$ & $1.6 \times 10^{-5}$ & $9.8 \times 10^{-1}$ & -- \\
\hline Top Fuel Guide & Stainless Steel & 450 & 24 & 0.3 & 1500 & $2.5 \times 10^{-3}$ & $1.5 \times 10^{-2}$ & $3.5 \times 10^{-5}$ & $7.6 \times 10^{-7}$ & $1.6 \times 10^{-5}$ & $9.8 \times 10^{-1}$ & -- \\
\hline Cone Support Plate & Stainless Steel & 10 & 11 & 2.4 & $4 . ?$ & $2.5 \times 10^{-3}$ & $1.5 \times 10^{-2}$ & $3.5 \times 10^{-5}$ & $7.6 \times 10^{-7}$ & $1.6 \times 10^{-5}$ & $9.8 \times 10^{-1}$ & -- \\
\hline Core Shroud & Staıniess Steel & 93240 & 47 & 4.1 & 22700 & $2.5 \times 10^{-3}$ & $1.5 \times 10^{-2}$ & $3.5 \times 10^{-5}$ & $7.6 \times 10^{-7}$ & $1.6 \times 10^{-5}$ & $9.8 \times 10^{-1}$ & -- \\
\hline Reactor Vessel wall & Carton Steol & 5 & 8 & 21.6 & 0.2 & $8.0 \times 10^{-3}$ & $1.7 \times 10^{-2}$ & -- & $3.2 \times 10^{-4}$ & $1.5 \times 10^{-5}$ & $9.8 \times 10^{-1}$ & -- \\
\hline Sacrificial Shield & Concrete & 1 & 90 & 90.0 & 0.01 & $1.0 \times 10^{-7}$ & $9.5 \times 10^{-3}$ & -- & $3.1 \times 10^{-4}$ & $9.6 \times 10^{-6}$ & $5.3 \times 10^{-1}$ & -- \\
\hline Totals & & 969533 & 228 & 124.1 & & & & & & & & \\
\hline
\end{tabular}

(a) Based on Table 1.3-3 of Reference 1.

(b) Mass divided by density where uass is fram Table 1.3-3 of Referenre 1.

(c) Radioartivity $\left(\mathrm{C}_{1}\right)$ divided by full-density volume.

(d) Based on Tables E.1-1, E.1-2, and F.1-3 of Reference 1.

(e) Correcter for radioactive decay on the hases of radimuclide inventories in Tables E.1-1, E.1-2, and F.1-3 of Reference 1 . 
IABLE 5.5. Neutron-Activated Materials from ENTOMB at the Reference BWR

\begin{tabular}{|c|c|c|c|c|c|c|c|c|c|c|c|c|}
\hline \multirow[b]{2}{*}{ Reactor Component } & \multirow[b]{2}{*}{ Material } & \multirow[b]{2}{*}{$\begin{array}{c}\text { Radionctiyity } \\
\text { (Ci) }\end{array}$} & \multirow[b]{2}{*}{$\begin{array}{l}\text { Burial } \\
\text { Volune } \\
\left(m^{3}\right)^{(a)}\end{array}$} & \multirow[b]{2}{*}{$\begin{array}{l}\text { Full-Density } \\
\text { Volume }(\mathrm{b}) \\
\left(\mathrm{m}^{3}\right)\end{array}$} & \multirow[b]{2}{*}{$\mathrm{Ci} / \mathrm{m}^{3(\mathrm{c})}$} & \multicolumn{4}{|c|}{$\begin{array}{l}\text { Fractional Radinact ivity } \\
\text { of Limiting Long- } \\
\text { Liver Nolides }\end{array}$} & \multicolumn{3}{|c|}{$\begin{array}{l}\text { Fractional Rarlinactivity } \\
\text { of Limiting Shorf- } \\
\text { Lived Nel ides }\end{array}$} \\
\hline & & & & & & ${ }^{14} \mathrm{C}$ & ${ }^{59} \mathrm{Ni}$ & $94 \mathrm{Bb}$ & ${ }^{99} \mathrm{TC}$ & ${ }^{60} \mathrm{CO}_{\mathrm{C}}$ & ${ }^{63} \mathrm{Ni}$ & $\begin{array}{l}\text { Less Than } \\
\text { 5-Year } \\
\text { Half-Life }\end{array}$ \\
\hline Stean Separator Assembly & Stainless Steel & 9600 & 10 & 1.2 & 8000 & $3.7 \times 10^{-5}$ & $2.2 \times 10^{-4}$ & $5.3 \times 10^{-7}$ & $1.1 \times 10^{-8}$ & $1.2 \times 10^{-1}$ & $\overline{3.1 \times 10^{-2}}$ & $8.5 \times 10^{-1}$ \\
\hline Fuel Support Pieces & Stainless Steel & 700 & 5 & 0.7 & 1000 & $3.7 \times 10^{-5}$ & $2.2 \times 10^{-4}$ & $5.3 \times 10^{-7}$ & $1.1 \times 10^{-8}$ & $1.2 \times 10^{-1}$ & $3.1 \times 10^{-2}$ & $8.5 \times 10^{-1}$ \\
\hline Control Rouk \& In-Cone Instrunents & Stainless Steel & 189000 & 15 & 2.5 & 75600 & $3.7 \times 10^{-5}$ & $2.2 \times 10^{-4}$ & $5.3 \times 10^{-7}$ & $1.1 \times 10^{-8}$ & $1.2 \times 10^{-1}$ & $3.1 \times 10^{-2}$ & $8.5 \times 10^{-1}$ \\
\hline Control Quide Tubes & Stainless Steel & 100 & 4 & 0.5 & 25 & $3.7 \times 10^{-5}$ & $2.2 \times 10^{-4}$ & $5.3 \times 10^{-7}$ & $1.1 \times 10^{-8}$ & $1.2 \times 10^{-1}$ & $3.1 \times 10^{-7}$ & $8.5 \times 10^{-1}$ \\
\hline Jet Punp Assenblies & Stainless Steel & 20000 & 14 & 0.8 & 200 & $3.7 \times 10^{-5}$ & $2.2 \times 10^{-4}$ & $5.3 \times 10^{-7}$ & $1.1 \times 10^{-8}$ & $1.2 \times 10^{-1}$ & $3.1 \times 10^{-2}$ & $8.5 \times 10^{-1}$ \\
\hline Top Fuel Quide & Stainless Steel & 30100 & 24 & 0.3 & 25000 & $3.7 \times 10^{-5}$ & $2.2 \times 10^{-4}$ & $5.3 \times 10^{-7}$ & $1.1 \times 10^{-8}$ & $1.2 \times 10^{-1}$ & $3.1 \times 10^{-2}$ & $8.5 \times 10^{-1}$ \\
\hline Core Support Plate & Stainless Steel & 650 & 11 & 2.4 & 100000 & $3.7 \times 10^{-5}$ & $2.2 \times 10^{-4}$ & $5.3 \times 10^{-7}$ & $1.1 \times 10^{-8}$ & $1.2 \times 10^{-1}$ & $3.1 \times 10^{-2}$ & $8.5 \times 10^{-1}$ \\
\hline Cone Shroud & Stainless Steel & 6300000 & 47 & 4.1 & 271 & $3.7 \times 10^{-5}$ & $2.2 \times 10^{-4}$ & $5.3 \times 10^{-7}$ & $1.1 \times 10^{-8}$ & $1.2 \times 10^{-1}$ & $3.1 \times 10^{-2}$ & $8.5 \times 10^{-1}$ \\
\hline Totals & & 6550150 & 130 & 12.5 & & & & & & & & \\
\hline
\end{tabular}

(a) Based on Table 1.3-3 of Reference 1.

(b) Mass divided by density where mass is from Table I.3-3 of Reference 1.

(c) Radioactivity (Ci) divided by full-density volıme.

(d) Based on Tables E.1-1, E.1-2, and F.1-3 of Reference 1. 
the concrete surfaces of these buildings are assumed to be contaminated and to require surface removal to a depth of about 50 millimeters.

Table 5.6 provides a summary of data on burial volumes, radioactivity (curie) contents, and fractional radioactivities of limiting short-lived radionuclides for contaminated materials from DECON at the reference BWR. Data on burial volumes are from Table I.3-4 of Reference 1. Data on curie contents are from Tables 7.4-10 and E.2-7 of Reference 1. Data on fractional radioactivities of limiting short-lived radionuclides are from Tables 7.4-6, 7.4-7, and 7.4-9 of Reference 1. For contaminated piping and equipment, the principal limiting short-lived isotope is ${ }^{60} \mathrm{Co}$ (half-life $=5.27$ years).

For contaminated structural surfaces, the principal limiting short-lived isotopes are ${ }^{60} \mathrm{Co}$ and ${ }^{137} \mathrm{Cs}$ (half-life $=30.0$ years). A comparison of Table 5.6 with Table 5.1 shows that the average concentrations of 1 imiting short-1ived radionuclides in contaminated materials are much smaller than the average concentrations of these same radionuclides in neutron-activated materials from DECON at the reference BWR. There are no significant quantities of limiting long-lived isotopes in contaminated materials.

For the SAFSTOR decommissioning alternative, contaminated materials are assumed to be disposed of during deferred dismantlement. The quantities of contaminated materials that require disposal are shown in Table 5.7 , which is taken from Table J.7-1 of Reference 1. The volume of contaminated material from deferred dismantlement 30 years after reactor shutdown is assumed in the reference study to be the same as the volume of contaminated material from immediate dismantlement $\left(17,229 \mathrm{~m}^{3}\right)$. For deferred dismantlement after 50 or 100 years, the volume of contaminated material for disposal is assumed to be on ly $150 \mathrm{~m}^{3}$. For deferred dismantlement 30 years after reactor shutdown, the ${ }^{60}$ Co concentration in contaminated materials will have decayed by about a factor of 50 and the ${ }^{137} \mathrm{Cs}$ concentration will have decayed by a factor of 2 . For deferred dismantlement after 50 years, the concentrations of ${ }^{60} \mathrm{Co}$ and ${ }^{137} \mathrm{Cs}$ in contaminated materials will have decayed by factors of about 700 and 3.2 , respectively For deferred dismantlement after 100 years, the concentrations of. ${ }^{60} \mathrm{Co}$ and ${ }^{137} \mathrm{Cs}$ in contaminated materials will have decayed by factors of about $5 \times 10^{5}$ and 10 , respectively.

For ENTOMB at a light-water reactor, much of the contaminated material from decommissioning operations can be placed in the entombment structure and entombed onsite, thus significantly reducing the amount of this material requiring offsite disposal. The volume of contaminated material requiring offsite disposal for ENTOMB at the reference BWR is estimated to be $6420 \mathrm{~m}^{3}$ (see Table K.3-4 of Reference 1). Data on burial volumes, curies, and fractional radioactivities of limiting short-lived radionuclides for contaminated materials from ENTOMB at the reference BWR are presented in Table 5.8 . 
TABLE 5.6. Contaminated Materials from DECON at the Reference BWR

\begin{tabular}{|c|c|c|c|c|c|c|c|c|}
\hline \multirow[b]{2}{*}{ Waste Category } & \multirow{2}{*}{$\begin{array}{c}\# \\
\text { Radioactivity } \\
\text { (Ci) }{ }^{(a)}\end{array}$} & \multirow{2}{*}{$\begin{array}{l}\text { Burial } \\
\text { Volume } \\
\left(\mathrm{m}^{3}\right)^{(\mathrm{b})} \\
\end{array}$} & \multirow[b]{2}{*}{$\mathrm{Ci} / \mathrm{m}^{3}$} & \multicolumn{5}{|c|}{$\begin{array}{l}\text { Fractional Radioactivity of } \\
\text { Limiting Short-Lived Nuclides }(c)\end{array}$} \\
\hline & & & & ${ }^{60} \mathrm{Co}_{0}$ & $63 \mathrm{Ni}^{\mathrm{N}}$ & $90 S r$ & ${ }^{137} \mathrm{Cs}_{\mathrm{s}}$ & $\begin{array}{l}\text { Other short- } \\
\text { lived }\end{array}$ \\
\hline Piping \& Valves & $2.2 \times 10^{3}$ & 4565 & 0.48 & $4.7 \times 10^{-1}$ & -- & -- & $3.4 \times 10^{-2}$ & $5.0 \times 10^{-1}$ \\
\hline Reactor Vessel & $9.4 \times 10^{2}$ & 493 & 1.91 & $4.7 \times 10^{-1}$ & - & -- & $3.4 \times 10^{-2}$ & $5.0 \times 10^{-1}$ \\
\hline Other Reactor Building Equipment & $9.4 \times 10^{2}$ & 1894 & 0.50 & $4.7 \times 10^{-1}$ & -- & -- & $3.4 \times 10^{-2}$ & $5.0 \times 10^{-1}$ \\
\hline Main Condenser & $3.9 \times 10^{2}$ & 1820 & 0.21 & $4.7 \times 10^{-1}$ & - & -- & $3.4 \times 10^{-2}$ & $5.0 \times 10^{-1}$ \\
\hline $\begin{array}{l}\text { Other Turbine-Generator Building } \\
\text { Equipment }\end{array}$ & $7.3 \times 10^{2}$ & 4426 & 0.16 & $4.7 \times 10^{-1}$ & -- & -- & $3.4 \times 10^{-2}$ & $5.0 \times 10^{-1}$ \\
\hline $\begin{array}{l}\text { Radwaste and Control Building } \\
\text { Equipment }\end{array}$ & $3.2 \times 10^{3}$ & 1431 & 2.24 & $4.7 \times 10^{-1}$ & -- & -- & $3.4 \times 10^{-2}$ & $5.0 \times 10^{-1}$ \\
\hline $\begin{array}{l}\text { Reactor Building Structural } \\
\text { Surfaces }\end{array}$ & $7.4 \times 10^{1}$ & 1941 & 0.038 & $2.9 \times 10^{-1}$ & $3.4 \times 10^{-3}$ & $1.5 \times 10^{-2}$ & $1.8 \times 10^{-1}$ & $5.1 \times 10^{-1}$ \\
\hline $\begin{array}{l}\text { Turbine-Generator Building } \\
\text { Structural Surfaces }\end{array}$ & $4.4 \times 10^{0}$ & 215 & 0.020 & $2.9 \times 10^{-1}$ & $3.4 \times 10^{-3}$ & $1.5 \times 10^{-2}$ & $1.8 \times 10^{-1}$ & $5.1 \times 10^{-1}$ \\
\hline $\begin{array}{l}\text { Radwaste and Control Building } \\
\text { Structural Surfaces }\end{array}$ & $3.5 \times 10^{1}$ & 444 & 0.081 & $2.9 \times 10^{-1}$ & $3.4 \times 10^{-3}$ & $1.5 \times 10^{-2}$ & $1.8 \times 10^{-1}$ & $5.1 \times 10^{-1}$ \\
\hline Totals & $8.5 \times 10^{3}$ & 17229 & & & & & & \\
\hline
\end{tabular}

(a) Based on Tables 7.4-10 and E.2-7 of Reference 1.

(b) Based on Table I.3-4 of Reference 1.

(c) Based on Tables 7.4-6, 7.4-7, and 7.4-9 of Reference 1. 
TABLE 5.7. Burial Volumes for Contaminated Materials from BWR Decommissioning

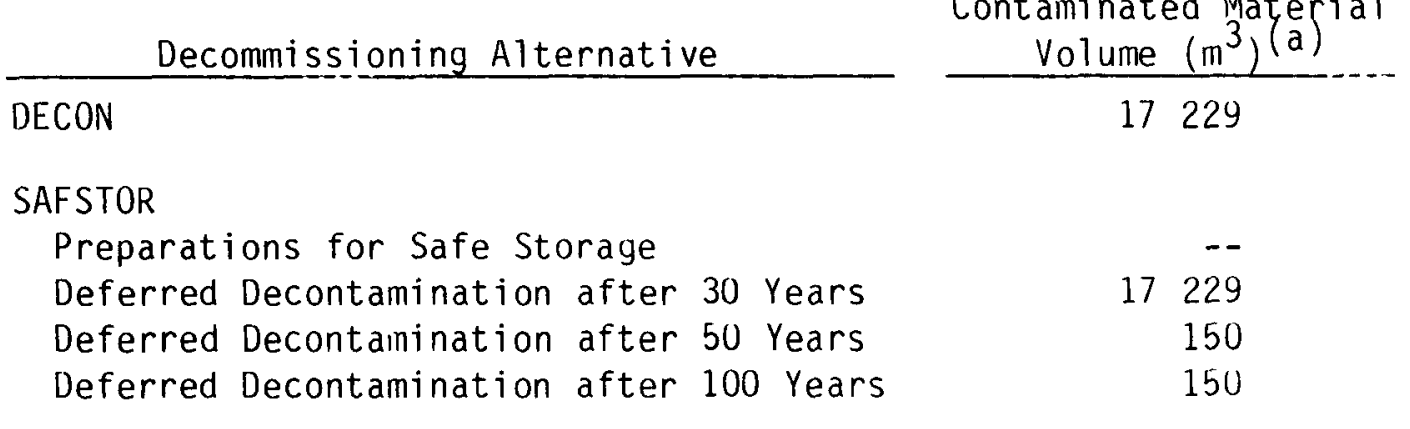

(a) From Table J.7-1 of Reference 1.

TABLE 5.8. Contaminated Materials from ENTOMB at the Reference BWR

\begin{tabular}{|c|c|c|c|c|c|c|c|c|}
\hline \multirow[b]{2}{*}{ Waste Category } & \multirow[b]{2}{*}{$\begin{array}{l}\text { Radioactivity } \\
(C i)^{(a)}\end{array}$} & \multirow{2}{*}{$\begin{array}{l}\text { Burial } \\
\text { Volume } \\
\left(\mathrm{m}^{3}\right)^{(b)}\end{array}$} & \multirow[b]{2}{*}{$\mathrm{Ci} / \mathrm{m}^{3}$} & \multicolumn{5}{|c|}{$\begin{array}{l}\text { Fractional Radioactivity of } \\
\text { Limiting Short-Lived Nuclides }(c)\end{array}$} \\
\hline & & & & $60_{0}$ & $63_{\mathrm{Ni}}$ & ${ }^{90} \mathrm{Sr}$ & ${ }^{137} \mathrm{Cs}$ & $\begin{array}{l}\text { Other short- } \\
\text { lived }\end{array}$ \\
\hline Reactor Building Equipment & 230 & 453 & 0.51 & $\overline{4.7 \times 10^{-1}}$ & -- & -- & $\overline{3.4 \times 10^{-2}}$ & $5.0 \times 10^{-1}$ \\
\hline Main Condenser & 390 & 1820 & 0.21 & $4.7 \times 10^{-1}$ & -- & -- & $3.4 \times 10^{-2}$ & $5.0 \times 10^{-1}$ \\
\hline $\begin{array}{l}\text { Other Turbine-Generator Building } \\
\text { Equiprent }\end{array}$ & 520 & 3252 & 0.16 & $4.7 \times 10^{-1}$ & -- & -- & $3.4 \times 10^{-2}$ & $5.0 \times 10^{-1}$ \\
\hline $\begin{array}{l}\text { Radwaste \& Control Building } \\
\text { Equiprent }\end{array}$ & 450 & 895 & 0.50 & $4.7 \times 10^{-1}$ & -- & - & $3.4 \times 10^{-2}$ & $5.0 \times 10^{-1}$ \\
\hline Totals & 1590 & 6420 & & & & & & \\
\hline
\end{tabular}

(a) Based on Tables 7.4-10 and E.2-7 of Refenence 1.

(b) Based on Table K.3-4 of Reference 1.

(c) Based on Table 7.4-6 of Reference 1.

\subsection{RADIOACTIVE WASTES}

Radioactive wastes from reactor decommissioning operations may be either wet solid wastes or dry solid wastes. Wet solid wastes result from the processing of chemical decontamination solutions and cuntaninated water volumes. These wastes include concentrator bottoms, filter sludges, and spent demineralizer resins, as well as neutralized chemical solutions from various decontamination operations. Wet solid wastes are mixed with a solidifying agent like cement to ensure retention of the radioactive materials within the shipping containers. Dry solid wastes include discarded contaminated materials such as rags and wipes, plastic sheeting, contaminated tools, and anti-contamination clothing. Table 5.9 gives a summary of data on waste volumes, curies, 
TABLE 5.9. Radioactive Wastes from Decommissioning at the Reference $B W R(a)$

\begin{tabular}{|c|c|c|c|c|c|c|c|c|}
\hline \multirow[b]{2}{*}{ Waste Type } & \multirow[b]{2}{*}{$\begin{array}{l}\text { Radioactivity } \\
\text { (C) }\end{array}$} & \multirow{2}{*}{$\begin{array}{l}\text { Burlal } \\
\text { Voluune } \\
\left(m^{3}\right)^{(b)}\end{array}$} & \multirow[b]{2}{*}{$\mathrm{Cl} / \mathrm{m}^{3}$} & \multicolumn{5}{|c|}{$\begin{array}{l}\text { Fractional Radioactivity of } \\
\text { Limting Short-Lived Nuclides }\end{array}$} \\
\hline & & & & $60 \mathrm{co}$ & $63_{N_{1}}$ & ${ }^{90} \mathrm{Sr}$ & ${ }^{137} \mathrm{Cs}$ & $\begin{array}{l}\text { Other short- } \\
\text { lived }\end{array}$ \\
\hline \multicolumn{9}{|l|}{ Wet Solind wastes } \\
\hline Concentrator Bottans & 31200 & $148(120)$ & 260 & $4.7 \times 10^{-1}$ & -- & -- & $3.4 \times 10^{-2}$ & $4.9 \times 10^{-1}$ \\
\hline Concentrator Bottans & 1296 & 307 (248) & 5.2 & $4.7 \times 10^{-1}$ & -- & -- & $3.4 \times 10^{-2}$ & $4.9 \times 10^{-1}$ \\
\hline Concentrator Bottans & 156 & $185(150)$ & 1.0 & $4.7 \times 10^{-1}$ & -- & - & $3.4 \times 10^{-2}$ & $4.9 \times 10^{-1}$ \\
\hline Sol idified Decontamnat ion Solns. & 101 & $120 \quad(95)$ & 1.1 & $4.7 \times 10^{-1}$ & -- & -- & $3.4 \times 10^{-2}$ & $4.9 \times 10^{-1}$ \\
\hline Filter Sludges and Resins & 228 & $54 \quad(42)$ & 5.4 & $4.7 \times 10^{-1}$ & -- & -- & $3.4 \times 10^{-2}$ & $4.9 \times 10^{-1}$ \\
\hline \multicolumn{9}{|l|}{ Dry Solıd Wastes } \\
\hline \multicolumn{9}{|l|}{ DECON } \\
\hline Shielded Drums & 1250 & 210 & 6.0 & $2.9 \times 10^{-1}$ & $3.4 \times 10^{-3}$ & $1.5 \times 10^{-2}$ & $1.8 \times 10^{-1}$ & $5.1 \times 10^{-1}$ \\
\hline Unshielded Drums & 556 & 468 & 1.2 & $2.9 \times 10^{-1}$ & $3.4 \times 10^{-3}$ & $1.5 \times 10^{-2}$ & $1.8 \times 10^{-1}$ & $5.1 \times 10^{-1}$ \\
\hline \multicolumn{9}{|l|}{ Preparations for Safe Storage } \\
\hline Shielded Drums & 440 & 75 & 6.0 & $2.9 \times 10^{-1}$ & $3.4 \times 1 \sigma^{-3}$ & $1.5 \times 10^{-2}$ & $1.8 \times 10^{-1}$ & $5.1 \times 10^{-1}$ \\
\hline Unshielded Drums & 197 & 166 & 1.2 & $2.9 \times 10^{-1}$ & $3.4 \times 10^{-3}$ & $1.5 \times 10^{-2}$ & $1.8 \times 10^{-1}$ & $5.1 \times 10^{-1}$ \\
\hline \multicolumn{9}{|l|}{ 30-Year Deferred Decontam nation } \\
\hline Shielded Drums & -- & -- & -- & -- & -- & -- & -- & -- \\
\hline Unshielded Drums & 132 & 437 & 0.30 & $5.0 \times 10^{-2}$ & $2.4 \times 10^{-2}$ & $6.4 \times 10^{-2}$ & $8.0 \times 10^{-1}$ & $6.4 \times 10^{-2}$ \\
\hline \multicolumn{9}{|l|}{ 50-Year Deferred Decontamination } \\
\hline Shrelded Orums & - & - & $\cdots$ & -- & - & -- & -- & -- \\
\hline Unshielded Drurrs & 80 & 350 & 0.23 & $5.9 \times 10^{-3}$ & $3.4 \times 10^{-2}$ & $6.4 \times 10^{-2}$ & $8.3 \times 10^{-1}$ & $6.4 \times 10^{-2}$ \\
\hline \multicolumn{9}{|l|}{ 100-Year Deferred Decontamination } \\
\hline Shielded Drums & -- & - & $\cdots$ & - & -- & -- & -- & -- \\
\hline Unshrelded Drums & 26 & 240 & 0.11 & $4.5 \times 10^{-4}$ & $7.2 \times 10^{-2}$ & $5.9 \times 10^{-2}$ & $8.1 \times 10^{-1}$ & $5.9 \times 10^{-2}$ \\
\hline \multicolumn{9}{|l|}{ ENTOMB } \\
\hline Shielded Drums & 1250 & 210 & 6.0 & $2.9 \times 10^{-1}$ & $3.4 \times 10^{-3}$ & $1.5 \times 10^{-2}$ & $1.8 \times 10^{-1}$ & $5.1 \times 10^{-1}$ \\
\hline Unshielded Drums & 556 & 468 & 1.2 & $2.9 \times 10^{-1}$ & $3.4 \times 10^{-3}$ & $1.5 \times 10^{-2}$ & $1.8 \times 10^{-1}$ & $5.1 \times 10^{-1}$ \\
\hline
\end{tabular}

(a) Data in this table are fram Sections H.5, I.3, J.5, and J.7 of Reference 1. See text for details.

(b) Values in parentheses for sol sold wastes are assumed solidified waste volumes used to calculate $\mathrm{C}_{1} / \mathrm{m}^{3}$.

and fractional radioactivities of limiting short-lived radionuclides for radioactive wastes from decommissioning at the reference BWR.

The operations of system decontamination, draining of contaminated water systems, and handling of the resultant radioactive liquids are assumed to be undertaken regardless of the alternative chosen for decommissioning of the reference BWR. Consequently, the volume of wet solid wastes from decominissioning operations is assumed to be the same for each alternative (DECON, SAFSTOR, or ENTOMB). Waste volume and curie data for wet solid wastes are taken from Section H.5.1.4 of Reference 1. Data on fractional radioactivity of limitiny short-lived nuclides for those wastes are from Table 7.4-6 of Reference 1. The processing of chemical decontamination solutions results in the production of $518 \mathrm{~m}^{3}$ of concreted waste (solidified concentrator bottoms) that is packaged in 
225 steel cask liners $\left(2.30 \mathrm{~m}^{3}\right.$ of concreted waste in each $2.84-\mathrm{m}^{3}$ liner $)$. Of the total volume of solidified concentrator bottoms, $120 \mathrm{~m}^{3}$ is assumed to have an average radioactivity concentration of $260 \mathrm{Ci} / \mathrm{m}^{3}, 248 \mathrm{~m}^{3}$ to have an average radioactivity concentration of $5.2 \mathrm{Ci} / \mathrm{m}^{3}$, and $150 \mathrm{~m}^{3}$ to have an average radioactivity concentration of $1.0 \mathrm{ci} / \mathrm{m}^{3}$. The neutralization and solidification of chemical decontamination solutions results in $95 \mathrm{~m}^{3}$ of concreted waste with a total radioactivity content of $101 \mathrm{Ci}$. The processing of contaminated water results in $42 \mathrm{~m}^{3}$ of filter sludges and spent demineralizer resins with a radioactivity content of $228 \mathrm{Ci}$. Cobalt-60 (half life $=5.27$ years) contributes almost half of the radioactivity of wet solid wastes.

Dry solid wastes from BWR decommissioning are assumed to be compacted and packaged in $0.21-\mathrm{m}^{3}$ standard steel drums for shipment to a burial ground. DECON, preparations for safe storage, and ENTOMB are all expected to result in some drums of dry solid waste that require shielding during transport, as well as drums which can be shipped unshielded. Dry solid wastes from deferred decontamination are assumed to be shipped in unshielded drums. Shielded drums are assumed to have maximum surface dose rates of $1.0 \mathrm{R} / \mathrm{hr}(1.25 \mathrm{Ci} / \mathrm{drum})$. Unshielded drums are assumed to have maximum surface dose rates of $0.2 \mathrm{R} / \mathrm{hr}$ $(0.25 \mathrm{Ci} / \mathrm{drum})$. Volumes of dry solid wastes from BWR decommissioning are taken from Tables I.3-5 (DECON and ENTOMB), J.5-3 (preparations for safe storage) and J.7-1 (deferred decontamination) of Reference 1. Data on fractional radioactivities of limiting short-lived nuclides for these wastes are from Table 7.4-7 of Reference 1. The principal short-lived nuclides in contaminated dry solid wastes are ${ }^{60} \mathrm{Co}$ (half-life 5.27 years) and ${ }^{137} \mathrm{Cs}$ (half-life 30.0 years). 


\subsection{CLASSIFICATION OF BWR DECOMMISSIONING WASTES}

A summary of waste class assignments for the radioactive wastes from conceptual decommissioning of the reference BWR is given in Table 6.1. Both the burial volumes of the waste and the percentages of total waste volume in each waste class are shown in the table. Waste class assignments are based on waste characterization data for the reference BWR summarized in Section 5 and on waste category definitions given in 10 CFR 61 and summarized in Tables 3.1 and 3.2 of this addendum.

Most of the radioactive waste from BWR decommissioning can be classified as Class $A$ waste. For the reference $B W R$, approximately $53 \mathrm{~m}^{3}$ (less than $1 \%$ of the burial volume) of the waste from DECON, 30-year SAFSTOR, and ENTOMB is estimated to be Class C waste. Approximately $39 \mathrm{~m}^{3}$ (about $2 \%$ of the burial volume) of the waste from 50-year SAFSTOR and 100-year SAFSTOR is estimated to be Class $C$ waste. Approximately $47 \mathrm{~m}^{3}(0.2 \%$ to $2.8 \%$ of the burial volume, depending on the decommissioning alternative) of the waste is estimated to exceed the Class $C$ limits of 10 CFR 61 . The Class $C$ waste and the waste that exceeds Class $C$ limits is neutron-activated material with high concentrations of ${ }^{59} \mathrm{Ni},{ }^{63} \mathrm{Ni}$, and ${ }^{94} \mathrm{Nb}$.

Details of the waste class assignments for neutron-activated materials, contaminated materials, and radioactive wastes from conceptual decommissioning of the reference BWR are given in the following sections.

\subsection{NEUTRON-ACTIVATED MATERIALS}

Waste class assignments for the neutron-activated materials from conceptual decommissioning of the reference BWR are given in Tables 6.2 through 6.5. Table 6.2 shows waste classes for neutron-activated materials removed from the primary containment during DECON. Tables 6.3 through 6.5 show waste classes for neutron-activated materials removed during deferred decontamination after shutdown periods of 30,50 , and 100 years. Table 6.6 shows waste classes for neutron-activated materials removed during ENTOMB at the reference BWR. Waste class assignments are determined by comparing the estimated concentrations of limiting long-lived and short-lived radionuclides in the waste with the concentrations used to define the different waste classes shown in Tables 3.1 and 3.2 of Section 3 . The estimated activity concentrations of limiting radionuclides shown in Tables 6.2 through 6.6 are determined by multiplying the specific activity $\left(\mathrm{Ci} / \mathrm{m}^{3}\right)$ of each activated component by the fractional radioactivity of the limiting radionuclides in the component. As explained in Section 5.1, the specific activity of neutron-activated material is based on the full-density volume rather than on the burial volume of the material. Values for fractional radioactivity of limiting long-lived and 
TABLE 6.1. Classification of Radioactive Wastes from BWR Decommissioning Waste Class Ass igment

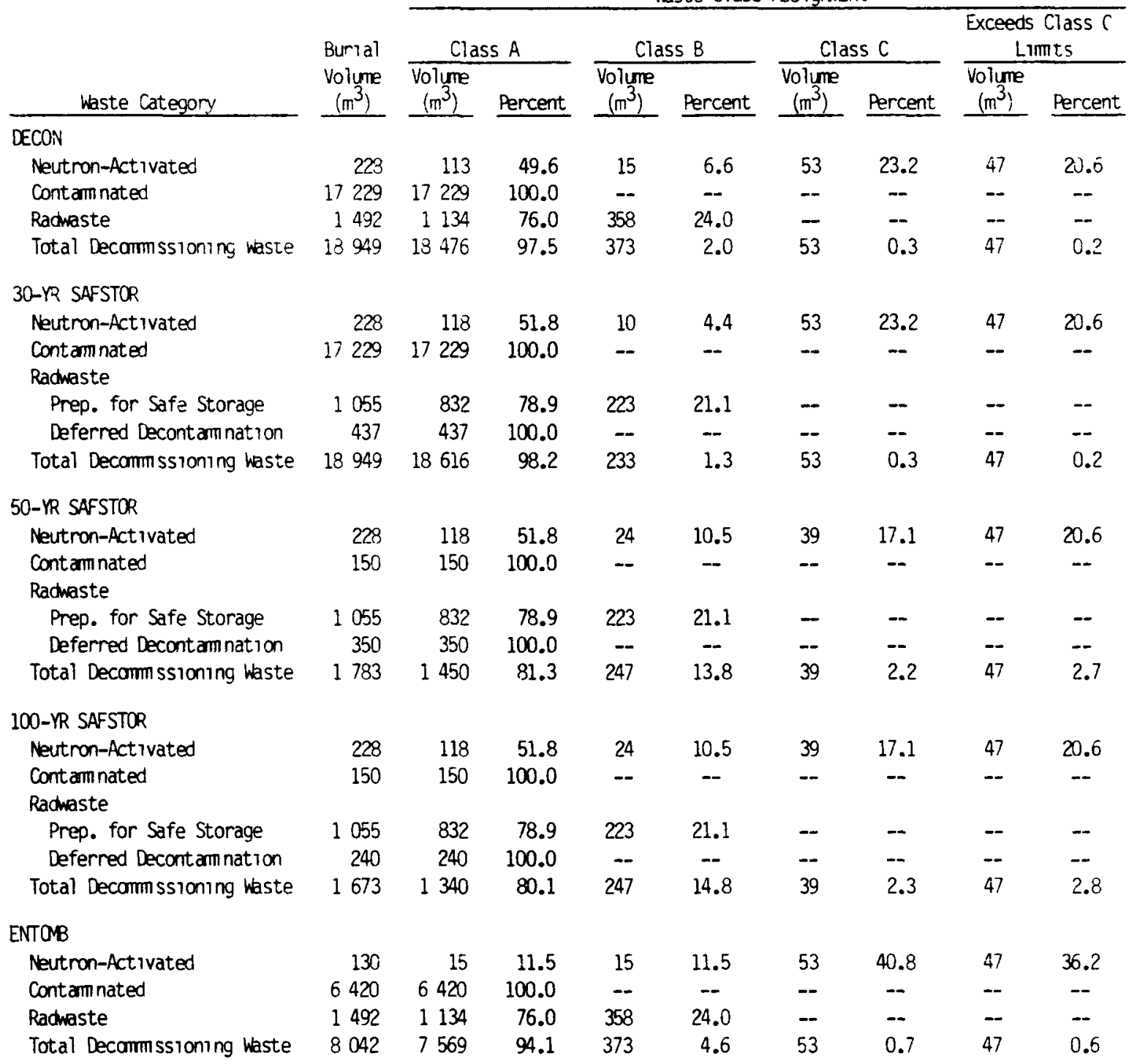


TA3l.F. 5.2. Waste Classifications of Neutron-Activated Materials from OECON at the Reference BWR

\begin{tabular}{|c|c|c|c|c|c|c|c|c|c|c|c|}
\hline \multirow{4}{*}{ Reactor Conponent } & \multirow{4}{*}{$\begin{array}{l}\text { Burial } \\
\text { Volume } \\
\left(\mathrm{m}^{3}\right) \\
\end{array}$} & \multirow{4}{*}{$\begin{array}{l}\text { Full } \\
\text { Density } \\
\text { Volune } \\
\left(\mathrm{mi}^{3}\right) \\
\end{array}$} & \multirow{4}{*}{$\begin{array}{l}\text { Total }(a) \\
\text { Specific } \\
\text { Activityy } \\
\left(\mathrm{Ci} / \mathrm{m}^{3}\right) \\
\end{array}$} & \multicolumn{7}{|c|}{ Specific Activity $\left(\mathrm{Ci} / \mathrm{m}^{3}\right)$} & \multirow[b]{4}{*}{$\begin{array}{l}\text { Whste } \\
\text { Class }\end{array}$} \\
\hline & & & & \multicolumn{4}{|c|}{ Limiting Long-Lived Niclides } & \multicolumn{3}{|c|}{ Limiting Short-Lived Nuclides } & \\
\hline & & & & & & & & & & Less Than & \\
\hline & & & & ${ }^{14} \mathrm{C}$ & ${ }^{59}{ }_{\mathrm{Ni}}$ & $91 \mathrm{~N}$ & ${ }^{99} \mathrm{TC}$ & ${ }^{60} \mathrm{Co}$ & $63_{\mathrm{Ni}}$ & $\begin{array}{c}\text { 5-Year } \\
\text { lalf-Life }\end{array}$ & \\
\hline Stean Separator Assenbly & 10 & 1.2 & 8000 & $3.0 \times 10^{-1}$ & $1.8 \times 10^{()}$ & $4.2 \times 10^{-3}$ & $8.8 \times 10^{-5}$ & $9.5 \times 10^{7}$ & $2.5 \times 11^{2}$ & $6.8 \times 11^{3}$ & $B$ \\
\hline Fuel Support Pieces & 5 & 0.7 & 1000 & $3.7 \times 10^{-2}$ & $2.2 \times 10^{-1}$ & $5.3 \times 10^{-4}$ & $1.1 \times 10^{-5}$ & $1.2 \times 10^{2}$ & $3.1 \times 11^{1}$ & $8.5 \times 111^{2}$ & B \\
\hline Control Rods and In-Core Instruments & 15 & 2.5 & 75600 & $2.8 \times 10^{0}$ & $1.7 \times 10^{1}$ & $4.0 \times 10^{-2}$ & $8.3 x^{10-4}$ & $9.1 \times 11^{3}$ & $2.3 \times 10^{3}$ & $6.7 \times 10^{4}$ & $\mathrm{c}$ \\
\hline Control Rod Quide Thes & 4 & 0.5 & 200 & $7.4 \times 10^{-3}$ & $4.4 \times 10^{-7}$ & $1.1 \times 10^{-4}$ & $2.2 \times 10^{-6}$ & $2.4 \times 10^{1}$ & $6.9 \times 111^{11}$ & $1.7 \times 10^{?}$ & $A$ \\
\hline Jet Punp Assemblies & 14 & 0.8 & 25000 & $9.2 \times 10^{-1}$ & $5.5 \times 10^{10}$ & $1.3 \times 10^{-2}$ & $2.8 \times 10^{-4}$ & $3.0 \times 10^{3}$ & $7.8 \times 11 \%^{2}$ & $2.1 \times 10^{4}$ & $\mathrm{c}$ \\
\hline Top Fuel Guide & 24 & 0.3 & 100000 & $3.7 \times 10^{0}$ & $2.2 \times 10^{1}$ & $5.3 \times 10^{-2}$ & $1.1 \times 10^{-3}$ & $1.2 \times 10^{4}$ & $3.1 \times 10^{3}$ & $8.5 \times 10^{4}$ & $c$ \\
\hline Core Support Plate & 11 & 2.4 & 271 & $1.0 \times 10^{-2}$ & $6.0 \times 10^{-2}$ & $1.4 \times 10^{-4}$ & $3.0 \times 10^{-6}$ & $3.2 \times 10^{1}$ & $8.4 \times 11^{())}$ & $2.3 \times 10^{2}$ & A \\
\hline Core Shroud & 47 & 4.1 & 1537000 & $5.7 \times 10^{1}$ & $3.4 \times 10^{2}$ & $8.1 \times 10^{-1}$ & $1.7 \times 10^{-2}$ & $1.8 \times 10^{5}$ & $4.8 \times 10^{4}$ & $1.3 \times 10^{6}$ & (b) \\
\hline Reactor Vessęl wall & 8 & 21.6 & 100 & $1.8 \times 10^{-3}$ & $4.0 \times 10^{-3}$ & -- & $7.2 \times 10^{-5}$ & $1.8 \times 10^{n}$ & $4.7 \times 10^{-1}$ & $9.8 \times 10^{1}$ & A \\
\hline Sacrificial Shield & 90 & 90.0 & 2 & $7.0 \times 10^{-5}$ & $6.4 \times 10^{-5}$ & -- & $2.2 \times 10^{-6}$ & $3.4 \times 10^{-2}$ & $7.6 \times 10^{-3}$ & $2.0 \times 10^{0}$ & $A$ \\
\hline
\end{tabular}

(a) Fram Table 5.1.

(b) Waste exceeds Class $\mathrm{C} 1 \mathrm{imits}$ because of high concentrations of ${ }^{59} \mathrm{Ni},{ }^{63} \mathrm{Ni}$, and ${ }^{94} \mathrm{Nb}$. 
TABLE 6.3. Waste Classifications of Neutron-Activated Materials from 30-Year Deferred Decontamination at the Reference BWR

Specific Activity $\left(\mathrm{Ci} / \mathrm{m}^{3}\right)$

\begin{tabular}{|c|c|c|c|c|c|c|c|c|c|c|c|}
\hline \multirow[b]{3}{*}{ Reactor Component } & \multirow[b]{3}{*}{$\begin{array}{l}\text { Burial } \\
\text { Volume } \\
\left(\mathrm{m}^{3}\right) \\
\end{array}$} & \multirow{3}{*}{$\begin{array}{l}\text { Ful1 } \\
\text { Density } \\
\text { Volume } \\
\left(\mathrm{m}^{3}\right) \\
\end{array}$} & \multirow{3}{*}{$\begin{array}{l}\text { Total (a) } \\
\text { Specific } \\
\text { Activity } \\
\left(\mathrm{Ci} / \mathrm{II}^{3}\right) \\
\end{array}$} & \multicolumn{7}{|c|}{ Specific Activity $\left(\mathrm{Ci} / \mathrm{m}^{3}\right)$} & \multirow[b]{3}{*}{$\begin{array}{l}\text { Waste } \\
\text { Class }\end{array}$} \\
\hline & & & & \multicolumn{4}{|c|}{ L initing Long-Lived No lides } & \multicolumn{2}{|c|}{ Liriting Short-Lived } & \multirow{2}{*}{$\begin{array}{l}\text { Nuclides } \\
\text { Less Than } \\
\text { 5-Year } \\
\text { Half-Life }\end{array}$} & \\
\hline & & & & ${ }^{14} \mathrm{C}$ & ${ }^{59} \mathrm{Ni}$ & $94 \mathbf{b}$ & ${ }^{99} \mathrm{IC}$ & ${ }^{6 n} \mathrm{Co}_{0}$ & $633 \mathrm{Ni}$ & & \\
\hline Steam Separator Assentbly & 10 & 1.2 & 217 & $\overline{3.0 \times 10^{-1}}$ & $\overline{1.8 \times 10^{0}}$ & $4.1 \times 10^{-3}$ & $\overline{8.9 \times 10^{-5}}$ & $\overline{1.8 \times 10^{1}}$ & $2.0 \times 10^{2}$ & $\overline{8.7 \times 10^{-1}}$ & $\overline{\mathrm{B}}$ \\
\hline Fuel Support Pieces & 5 & 0.7 & 29 & $4.1 \times 10^{-2}$ & $2.4 \times 10^{-1}$ & $5.5 \times 10^{-4}$ & $1.2 \times 10^{-5}$ & $2.4 \times 10^{0}$ & $2.6 \times 10^{1}$ & $1.2 \times 10^{-1}$ & A \\
\hline Control Rods and In-Core Instruments & 15 & 2.5 & 2060 & $2.9 \times 10^{0}$ & $1.7 \times 10^{1}$ & $3.9 \times 10^{-2}$ & $8.4 \times 10^{-4}$ & $1.7 \times 10^{2}$ & $1.8 \times 10^{3}$ & $8.2 \times 10^{0}$ & $\mathrm{c}$ \\
\hline Control Rod Guide Tubes & 4 & 0.5 & 6 & $8.4 \times 10^{-3}$ & $4.9 \times 10^{-2}$ & $1.1 \times 10^{-4}$ & $2.5 \times 10^{-6}$ & $5.0 \times 10^{-1}$ & $5.4 \times 10^{0}$ & $2.4 \times 10^{-1}$ & A \\
\hline Jet Punp Assentilies & 14 & 0.8 & 675 & $9.4 \times 10^{-1}$ & $5.5 \times 10^{0}$ & $1.3 \times 10^{-2}$ & $2.8 \times 10^{-4}$ & $5.7 \times 10^{1}$ & $6.1 \times 10^{2}$ & $2.7 \times 10^{0}$ & $c$ \\
\hline Top Fuel Guide & 24 & 0.3 & 2730 & $3.8 \times 10^{0}$ & $2.2 \times 10^{1}$ & $5.2 \times 10^{-2}$ & $1.1 \times 10^{-3}$ & $2.3 \times 10^{2}$ & $2.5 \times 10^{3}$ & $1.1 \times 10^{1}$ & c \\
\hline Core Support Plate & 11 & 2.4 & 8.3 & $1.2 \times 10^{-2}$ & $6.8 \times 10^{-2}$ & $1.6 \times 10^{-4}$ & $3.4 \times 10^{-6}$ & $7.0 \times 10^{-1}$ & $7.5 \times 10^{0}$ & $3.3 \times 10^{-2}$ & A \\
\hline Core Shroud & 47 & 4.1 & 41800 & $5.8 \times 10^{1}$ & $3.4 \times 10^{2}$ & $7.9 \times 10^{-1}$ & $1.7 \times 10^{-2}$ & $3.5 \times 10^{3}$ & $3.8 \times 10^{4}$ & $1.7 \times 10^{2}$ & (b) \\
\hline Reactor Vessel Wall & 8 & 21.6 & 0.5 & $2.1 \times 10^{3}$ & $4.5 \times 10^{3}$ & -- & $8.0 \times 10^{5}$ & $3.9 \times 10^{-2}$ & $4.2 \times 10^{-1}$ & $3.5 \times 10^{-2}$ & A \\
\hline Sacrificial Shield & 90 & 90.0 & 0.01 & $5.8 \times 10^{-5}$ & $5.3 \times 10^{-5}$ & -- & $1.7 \times 10^{-6}$ & $5.3 \times 10^{-4}$ & $5.0 \times 10^{-3}$ & $1.2 \times 10^{-3}$ & A \\
\hline
\end{tabular}

(a) From Table 5.2.

(b) Whate exceds Class C limits because of high concentrations of ${ }^{59} \mathrm{Ni},{ }^{63} \mathrm{Ni}$, and ${ }^{94} \mathrm{Nb}$. 
TABLE 6.4. Wasta Classifications of Neutron-Activated Materials from 50-Year Deferred Decontamination at the Reference BWR

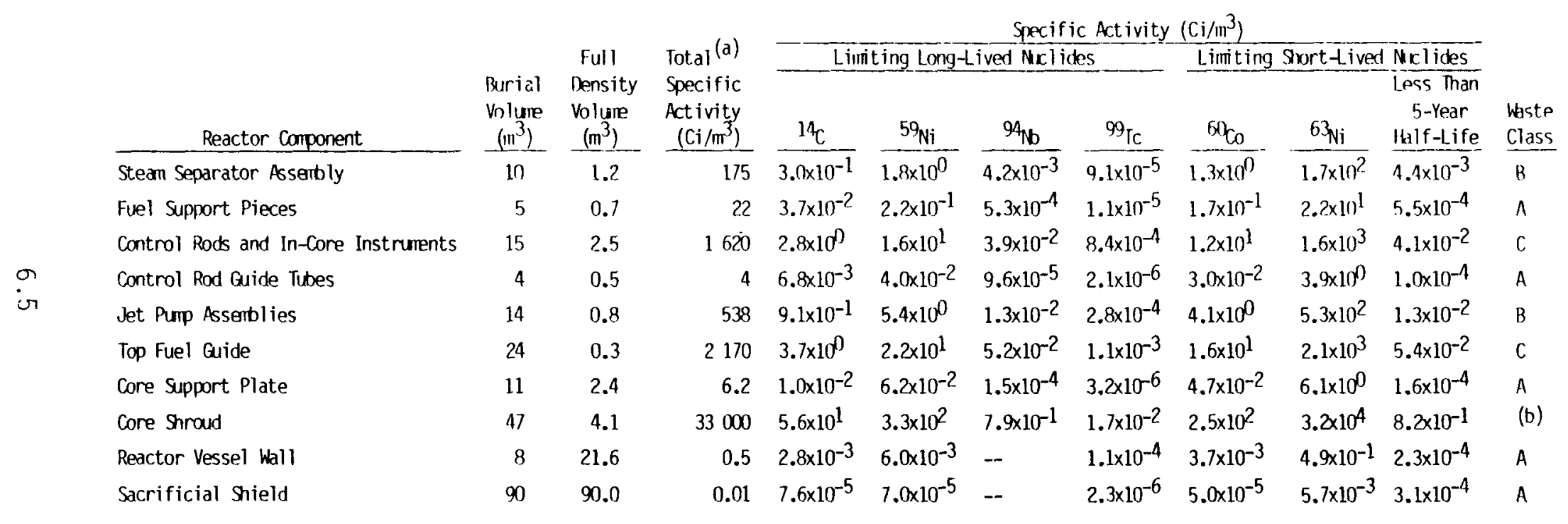

(a) Fram Table 5.3.

(b) Waste exceeds Class $\mathrm{C}$ limits because of high concentrations of ${ }^{59} \mathrm{Ni}, 53_{\mathrm{Ni}}$, and ${ }^{94} \mathrm{~W}$. 
TABLE 6.5. Waste Classifications of Neutron-Activated Materials from 100-Year Deferred Decontamination at the Reference BWR

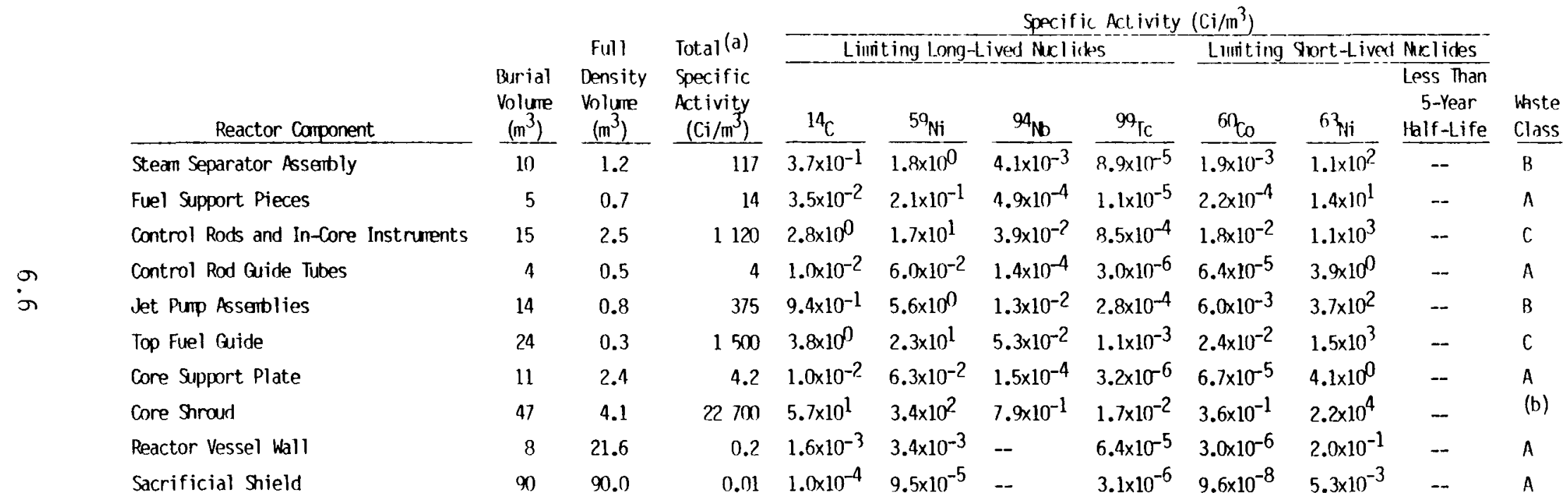

(a) Fran Table 5.4.

(b) Waste exceeds Class C 1 imits because of high concentrations of ${ }^{59} \mathrm{Ni}, 63_{\mathrm{Ni}}$, and ${ }^{94} \mathrm{Nb}$. 
SABLt h.t. Wasto s.lassifications of Neutron-Activated Materials from ENTUMB at the Reference BWR

\begin{tabular}{|c|c|c|c|c|c|c|c|c|c|c|c|}
\hline \multirow[b]{3}{*}{ Reactor Component } & \multirow{3}{*}{$\begin{array}{l}\text { Burial } \\
\text { Volume } \\
\left(\mathrm{m}^{3}\right)\end{array}$} & \multirow{3}{*}{$\begin{array}{l}\text { Full } \\
\text { Density } \\
\text { Volume } \\
\left(\mathrm{m}^{3}\right) \\
\end{array}$} & \multirow{3}{*}{$\begin{array}{l}\text { Total } \\
\text { Specific } \\
\text { Activity } \\
\left(\mathrm{Ci} / \mathrm{m}^{3}\right) \\
\end{array}$} & \multicolumn{7}{|c|}{ Specific Activity $\left(\mathrm{Ci} / \mathrm{m}^{3}\right)$} & \multirow[b]{3}{*}{$\begin{array}{l}\text { Waste } \\
\text { Class }\end{array}$} \\
\hline & & & & \multicolumn{4}{|c|}{ Limiting Long-Lived Nolides } & \multicolumn{2}{|c|}{ Limiting Short-Lived } & \multirow{2}{*}{$\begin{array}{c}\text { Niclides } \\
\text { Less Than } \\
5-\text { Year } \\
\text { lbalf-Life }\end{array}$} & \\
\hline & & & & $14 \mathrm{C}$ & ${ }^{59_{\mathrm{Ni}}}$ & ${ }^{94} \mathrm{~b}$ & ${ }^{99} \mathrm{TC}$ & $60_{C 0}$ & $63_{\mathrm{Ni}}$ & & \\
\hline Steam Separator Assembly & 10 & 1.2 & 8000 & $3.0 \times 10^{-1}$ & $1.8 \times 10^{0}$ & $4.2 \times 10^{-3}$ & $8.8 \times 10^{-5}$ & $9.6 \times 10^{2}$ & $2.5 \times 10^{2}$ & $6.8 \times 10^{3}$ & $B$ \\
\hline Fuel Support Pieces & 5 & 0.7 & 1000 & $3.7 \times 10^{-2}$ & $2.2 \times 10^{-1}$ & $5.3 \times 10^{-4}$ & $1.3 \times 10^{-5}$ & $1.2 \times 10^{2}$ & $3.1 \times 10^{1}$ & $8.5 \times 10^{2}$ & B \\
\hline Control Rods and In-Core Instruments & 15 & 2.5 & 75600 & $2.8 \times 10^{0}$ & $1.7 \times 10^{1}$ & $4.0 \times 10^{-2}$ & $8.3 \times 10^{-4}$ & $9.1 \times 10^{3}$ & $2.3 \times 10^{3}$ & $6.4 \times 10^{4}$ & c \\
\hline Contmol Rod Fuide Tibes & 4 & 0.5 & 200 & $7.4 \times 10^{-3}$ & $4.4 \times 10^{-2}$ & $1.1 \times 10^{-4}$ & $2.2 \times 10^{-6}$ & $2.4 \times 10^{1}$ & $6.2 \times 10^{0}$ & $1.7 \times 10^{2}$ & A \\
\hline Jet Punp Assenblies & 14 & 0.8 & 25000 & $9.2 \times 10^{-1}$ & $5.5 \times 10^{9}$ & $1.3 \times 10^{-2}$ & $2.8 \times 10^{-4}$ & $3.0 \times 10^{3}$ & $7.8 \times 10^{2}$ & $2.1 \times 10^{4}$ & c \\
\hline Top Fuel Quide & 24 & 0.3 & 100000 & $3.7 \times 10^{0}$ & $2.2 \times 10^{1}$ & $5.3 \times 10^{-2}$ & $1.1 \times 10^{-3}$ & $1.2 \times 10^{4}$ & $3.1 \times 10^{3}$ & $8.5 \times 10^{4}$ & c \\
\hline Core Support Plate & 11 & 2.4 & 271 & $1.0 \times 10^{-2}$ & $6.0 \times 10^{-2}$ & $1.4 \times 10^{-4}$ & $3.0 \times 10^{-6}$ & $3.2 \times 10^{1}$ & $8.4 \times 10^{0}$ & $2.3 \times 10^{2}$ & A \\
\hline Cone Shroud & 47 & 4.1 & 1537000 & $5.7 \times 101$ & $3.4 \times 10^{2}$ & $8.1 \times 10^{-1}$ & $1.7 \times 10^{-2}$ & $1.8 \times 10^{5}$ & $4.8 \times 10^{4}$ & $1.3 \times 10^{6}$ & (b) \\
\hline Reactor Vessel Wall & 8 & - & -- & -- & -- & -- & - & -- & -- & -- & -- \\
\hline Sacrificial Shield & 90 & -- & -- & -- & -- & -- & -. & -- & -- & -- & -. \\
\hline
\end{tabular}

(a) Fran Table 5.5.

(b) Waste exceeds Class C limits because of high concentrations of ${ }^{59} \mathrm{Ni},{ }^{63} \mathrm{Ni}$, and ${ }^{94} \mathrm{~N}$. 
short-lived radionuclides for the various neutron-activated components are given in Tables 5.1 through 5.5 of Section 5 .

As shown in Tables 6.2 through 6.6 , the concentrations of limiting radionuclides in much of the neutron-activated material from decommissioning of the reference BWR are low enough to permit the classification of this material as either Class A or Class B waste. However, the concentrations of ${ }^{63} \mathrm{Ni}$ and $94 \mathrm{Nb}$ in the control rods and in-core instruments, the jet pump assembiies, and top fuel guide require that this material be classified as $\mathrm{Class} C$ waste. The concentrations of ${ }^{59} \mathrm{Ni},{ }^{63} \mathrm{Ni}$, and ${ }^{94} \mathrm{Nb}$ in the core shroud exceed values for Class $C$ waste. Because of the long half-lives of these isotopes, the radioactivity in these neutron-activated materials is not significantly reduced by deferring their removal for periods of up to 100 years. Thus, they retain their status as $\mathrm{Cl}$ ass $\mathrm{C}$ waste or as waste exceeding $\mathrm{Class} \mathrm{C}$ limits even for deferred decontamination 100 years after reactor shutdown. (The jet pump assemblies from decommissioning of the reference BWR are classified as Class $B$ waste for deferred decontamination periods of 50 and 100 years.)

\subsection{CONTAMINATED MATERIALS}

Waste classes of contaminated materials from conceptual decommissioning of the reference BWR by the DECON alternative are shown in Table 6.7. The estimated activity concentrations for limiting short-lived nuclides shown in Table 6.7 are obtained by multiplying the specific activity $\left(\mathrm{Ci} / \mathrm{m}^{3}\right)$ of the material in each waste category by the fractional radioactivity of the limiting radionuclides in the material as shown in Table 5.6 of Section 5 . Because of the low concentrations of limiting radionuclides in contaminated material, all of this material is classified as Class A waste.

As discussed previously in Section 5.2, the contaminated materials from decommissioning of the reference BWR by the SAFSTOR or ENTOMB alternatives have limiting radionuclide concentrations that are equal to or less than the concentrations in contaminated materials from DECON. Therefore, contaminated materials from decommissioning of the reference BWR by the SAFSTOR and ENTOMB alternatives are also classified as Class $A$ waste.

\subsection{RADIOACTIVE WASTES}

Waste class assignments for. the radioactive wastes from conceptual decommissioning of the reference BWR are given in Table 6.8. Waste classes are determined by comparing the estimated concentrations of limiting short-lived radionuclides in the waste with the concentrations used to define the different waste classes shown in Table 3.2 of Section 3 . The estimated activity concentrations shown in Table 6.8 are obtained by multiplying the specific activity 
TABLE 6.7. Waste Classifications of Contaminated Materials from DECON at the Reference BWR

\begin{tabular}{|c|c|c|c|c|c|c|c|c|}
\hline \multirow[b]{2}{*}{ Waste Type } & \multirow{2}{*}{$\begin{array}{c}\text { Burial } \\
\text { Volune } \\
\left(\mathrm{m}^{3}\right)\end{array}$} & \multirow[b]{2}{*}{$\left(\mathrm{Cl} / \mathrm{m}^{3}\right)$} & \multicolumn{6}{|c|}{ Specific Activity $\left(\mathrm{C} / \mathrm{m}^{3}\right)$} \\
\hline & & & $6 q_{0}$ & $63 \mathrm{Ni}$ & $90_{S r}$ & ${ }^{137} \mathrm{Cs}$ & $\begin{array}{c}\text { Other } \\
\text { Short-lived }\end{array}$ & $\begin{array}{l}\text { Waste } \\
\text { Class } \\
\end{array}$ \\
\hline Reactor Vessel & 493 & 1.91 & $9.0 \times 10^{-1}$ & - & -- & $6.5 \times 10^{-2}$ & $9.6 \times 10^{-1}$ & A \\
\hline Main Condenser & 1820 & 0.21 & $9.9 \times 10^{-2}$ & -- & - & $7.1 \times 10^{-3}$ & $1.0 \times 10^{-1}$ & A \\
\hline Piping and Valves & 4. 565 & 0.48 & $2.2 \times 10^{-1}$ & -- & -- & $1.6 \times 10^{-2}$ & $2.4 \times 10^{-1}$ & $A$ \\
\hline Reactor Building Equipment & 1894 & 0.50 & $2.4 \times 10^{-1}$ & - & -- & $1.7 \times 10^{-2}$ & $2.5 \times 10^{-1}$ & A \\
\hline $\begin{array}{l}\text { Turbine-Generator Building } \\
\text { Equipment. }\end{array}$ & 4426 & 0.16 & $7.5 \times 10^{-2}$ & -- & - & $5.4 \times 10^{-3}$ & $8.0 \times 10^{-2}$ & A \\
\hline $\begin{array}{l}\text { Radwaste and Control Bullding } \\
\text { Equi pment }\end{array}$ & 1431 & 2.24 & $1.0 \times 10^{0}$ & -- & - & $7.6 \times 10^{-2}$ & $1.1 \times 10^{0}$ & A \\
\hline Reactor Burlding Structural Surfaces & 1941 & 0.038 & $1.1 \times 10^{-2}$ & $1.3 \times 10^{-4}$ & $5.7 \times 10^{-4}$ & $6.8 \times 10^{-3}$ & $1.9 \times 10^{-2}$ & A \\
\hline $\begin{array}{l}\text { Turbine-Cenerator Builing } \\
\text { Structural Surfaces }\end{array}$ & 215 & 0.020 & $5.8 \times 10^{-3}$ & $6.8 \times 10^{-5}$ & $3.0 \times 10^{-4}$ & $3.6 \times 10^{-3}$ & $1.0 \times 10^{-2}$ & A \\
\hline $\begin{array}{l}\text { Radwaste and Control Building } \\
\text { Structural Surfaces }\end{array}$ & 444 & 0.081 & $2.3 \times 10^{-2}$ & $2.8 \times 10^{-4}$ & $1.2 \times 10^{-3}$ & $1.4 \times 10^{-2}$ & $4.1 \times 10^{-2}$ & A \\
\hline
\end{tabular}

TABLE 6.8. Waste Classifications of Radioactive Wastes from Decommissioning at the Reference BWR

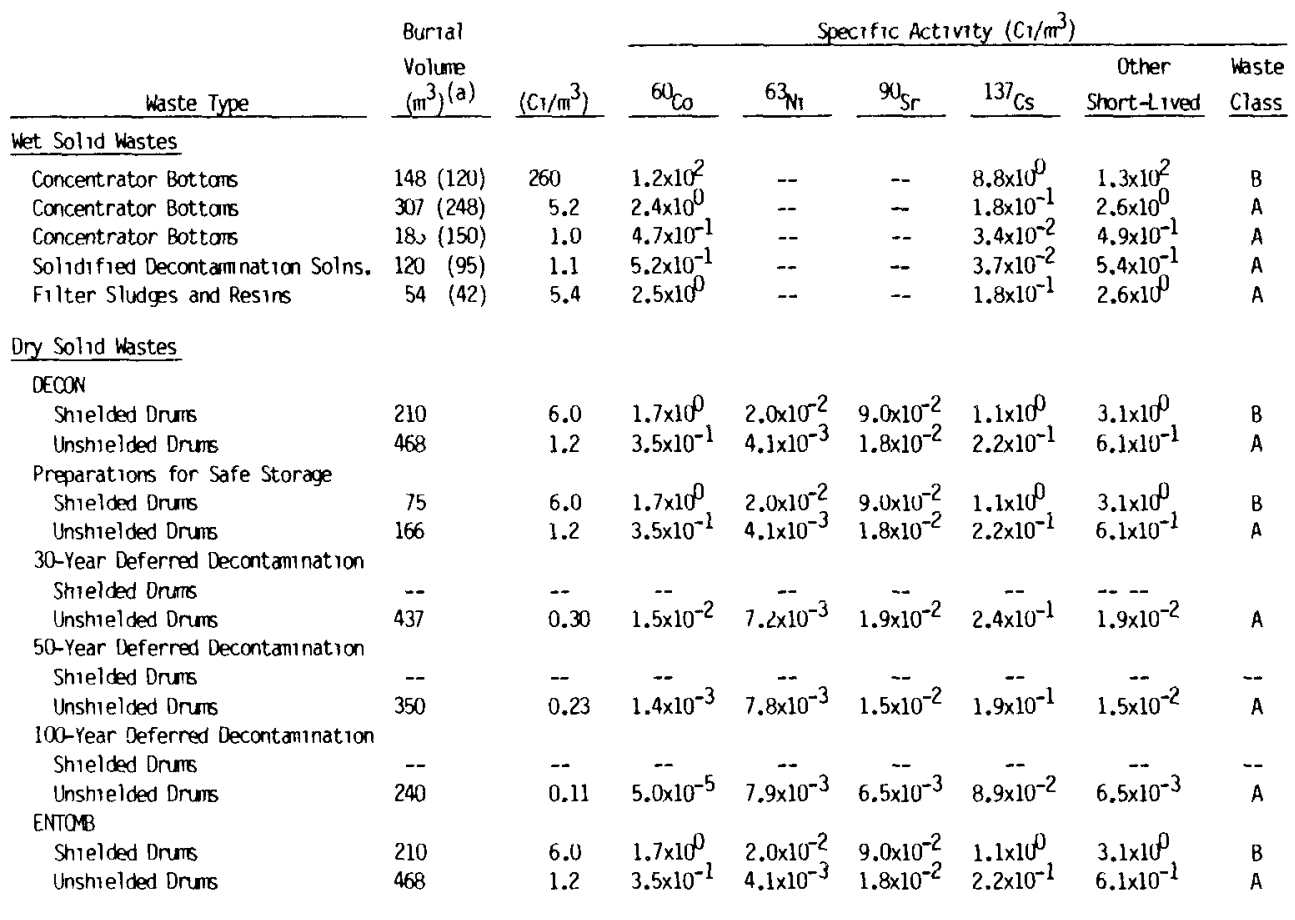

(a) Values in parentheses for wet solid wastes are actual solıdi fied weste volumes used to calaulate $\mathrm{Cl} / \mathrm{m}^{3}$.

of a given waste type by the fractional radioactivity of the short-lived radionuclides in the waste as shown in Table 5.9 of Section 5 .

As discussed previously in Section 5 , the operations of system decontamination and processing of radioactive liquids are assumed to be undertaken 
regardless of the alternative chosen to decommission the facility. Consequently, the burial volumes and specific activities of the wet solid wastes from decommissioning operations are the same for each decommissioning alternative (DECON, SAFSTOR, and ENTOMB). Approximately $82 \%$ (by volume) of the solidified wet wastes from BWR decommissioning are estimated to be Class A wastes, and the remaining wastes (solidified concentrator bottoms with high specific activity) are Class B.

Most of the dry solid wastes from BWR decommissioning operations can be classified as Class A waste. Because of high concentrations of ${ }^{137} \mathrm{Cs}$, approximately $31 \%$ (by volume) of the dry solid waste from DECON, preparations for safe storage, and ENTOMB of the reference BWR is estimated to be Class B waste. 


\subsection{CONCLUSIONS}

The nuclear wastes from conceptual decommissioning of a reference BWR are classified, in this addendum, in terms of the waste classes specified in 10 CFR 61. The results are tabulated in Table 6.1 of Section 6 .

Most of the nuclear waste from BWR decommissioning (approximately $80 \%$ to $98 \%$ of the total waste volume, depending on the decommissioning alternative) is considered to have such low radionuclide concentrations that it can be classified as Class $A$ waste. To be acceptable for shallow-land disposal, Class A waste must meet the minimum packaging and waste form requirements given in paragraph $61.56(\mathrm{a})$ of $10 \mathrm{CFR}$. The waste processing and packaging methods described in the reference BWR study (Reference 1) provide sufficient protection to permit the handling and disposal of these wastes at a licensed shallowland disposal site without further packaging requirements.

A small fraction of the nuclear waste from BWR decommissioning (approximately $1.3 \%$ to $15 \%$ of the total waste volume, depending on the decommissioning alternative) is classified as Class $B$ waste. For the reference BWR, the Class $B$ waste includes some neutron-activated stainless steel components with ${ }^{63} \mathrm{Ni}$ concentrations that exceed Class A limits, concentrator bottoms with high specific activity from the processing of radioactive liquids, and some dry solid waste with concentrations of short-lived radionuclides that exceed Class A limits. Class $B$ waste must meet the stability requirements of 10 CFR 61.56(b) that are intended to provide protection against structural degradation following burial. Structural stability can be provided by the waste form itself, by processing the waste to a stable form, or by placing the waste in a disposable container that provides stability after disposal. The processing and packaging methods described in the reference study provide adequate stability for most of the Class B waste identified in the study. However, in processing Class $B$ wet or liquid waste, care must be taken to ensure that the residual liquid does not exceed $1 \%$ of the volume of the waste when the waste is in a disposal container designed to ensure stability, or $0.5 \%$ of the volume of the waste for waste processed to a stable form.

Some of the neutron-activated stainless steel components removed from the reactor pressure vessel during decommissioning are considered to have such high concentrations of ${ }^{59} \mathrm{Ni}, 63 \mathrm{Ni}$, and ${ }^{94} \mathrm{Nb}$ that they exceed the classification criteria for Class $A$ and Class B wastes. The control rods and in-core instruments (burial volume $15 \mathrm{~m}^{3}$ ), jet pump assemblies (burial volume $14 \mathrm{~m}^{3}$ ), and top fuel guide (burial volume $24 \mathrm{~m}^{3}$ ) are all classified as Class $C$ waste in this study. The core shroud (burial volume $47 \mathrm{~m}^{3}$ ) is considered to exceed Class $\mathrm{C}$ limits in terms of the limiting concentrations of long-lived radionuclides specified in 10 CFR 61. 
Class $C$ waste must meet the stability requirements of 10 CFR $61.56(b)$ and must also be disposed of by a burial site operator using methods that provide additional protection against inadvertent intrusion into the burial ground. Class $C$ waste must be buried so that the top of the waste is a minimum of 5 meters below the top surface of the cover, or must be placed within intruder barriers that are designed to protect against an inadvertent intrusion for at least 500 years. The disposal costs for Class $C$ waste could be significantiy higher than the disposal costs for Class A and Class B wastes. An estimate of these higher costs is beyond the scope of this addendum and is not given here.

Such nuclear waste as the core shroud that exceeds Class C limits according to the provisions of 10 CFR 61 is generally unacceptable for routine nearsurface disposal. The licensee is required to safely store this waste until a specific determination can be made on its disposition. Onsite storage of decommissioning waste would prevent termination of the nuclear license and release of the site until the waste was subsequently removed to an offsite disposal facility. The prospect of onsite storage of nuclear waste for a protracted period could therefore affect the choice of an alternative to decommission the reactor.

Two recent PNL experimental studies $(6,7)$ that characterize the radioactivity concentrations in contaminated and activated materials from nuclear power plants provide data for comparison with the waste classification results summarized above.

In one of the studies, (6) onsite sampling and measurement programs were conducted at 7 nuclear power plants ( 4 BWRs and 3 PWRs) to assess the residual radionuclide concentrations and inventories in contaminated piping, hardware, equipment, concrete, and soils. The residual radionuclide concentrations observed in these contaminated materials were compared with guidelines for shallow-land burial of low-level radioactive waste contained in 10 CFR 61 . The study concluded that the entire components of a decommissioned nuclear power plant (exclusive of the reactor pressure vessel and internals) could be disposed of at a shallow-land burial site as Class $A$ waste, either directly or by mixing the relatively small quantities of highly contaminated concrete with lower-activity wastes. (The study did not address the question of wastes from the processing of contaminated water volumes or decontamination solutions, some of which are considered in this addendum to be Class $B$ wastes.)

In the second study, (7) a program was carried out to assess the problems posed to reactor decommissioning by long-lived activation products in reactor construction materials. Reactor components investigated included the bioshield, the pressure vessel, the vessel cladding, and the stainless steel internals. The program included the following three steps: 
1. Samples of stainless steel, vessel steel, concrete, and concrete ingredients were analyzed to develop a data base of major, minor, and trace elements that are capable of being activated.

2. Calculations were performed using average values of the measured compositions of the appropriate materials to predict the levels of activation products expected in reactor internals, vessel walls, and bioshield materials for both BWRs and PWRs.

3. Selected samples of activated steel and concrete were subjected to limited radiochemical analyses as a verification of the computer model used for the calculations of Step 2.

A comparison was made between calculated activation levels and regulatory guidelines for shallow-land disposal according to 10 CFR 61. It was concluded that the BWR core shroud does not appear to be suitable for disposal as lowlevel waste. From an activation standpoint, the remaining components were determined to be either Class $A$ or Class $B$ waste, with the sacrificial shield concrete (i.e., the bio-shield) clearly Class $A$ even at its highest point of activation.

In this addendum, the core shroud is considered not classifiable as lowlevel waste. The control rods and in-core instruments, jet pump assemblies, and top fuel guide are considered Class $C$ wastes. The remaining components are considered $\mathrm{Class} \mathrm{A}$ and $\mathrm{Cl}$ ass $\mathrm{B}$ wastes. The sacrificial shield is considered Class $A$ waste. Thus, the results of the two studies cited in Reference 7 and Reference 8 are in substantial agreement with results reported in this addendum for the conceptual decommissioning of a reference BWR. 


\subsection{REFERENCES}

1. H. D. Oak, et al., Technology, Safety and Costs of Decommissioning a Reference Boiling Water Reactor Power Station, NUREG/CR-0672, Pacific Northwest Laboratory for U.S. Nuclear Regulatory Commission, June 1980.

2. "Licensing Requirements for the Land Disposal of Radioactive Waste," Federal Register, Vol. 47, No. 248, 27 Dec. 1982, pp. 57446-57482.

3. Final Waste Classification and Waste Form Technical Position Papers, U.S. Nuclear Regulatory Commission, Washington, D.C., May 11, 1983.

4. G. D. Calkins, Plan for Reevaluation of NRC Policy on Decommissioning of Nuclear Facilities, NUREG-0436, Revision 1, Supplement 1, U.S. Nuclear Regulatory Commission, Washington, D.C., August 1980.

5. Draft Generic Environmental Impact Statement on Decommissioning of Nuclear Facilities, NUREG-0586, U.S. Nuclear Regulatory Commission, Washington, D.C., January 1981.

6. D. E. Robertson, et al., Residual Radionuclide Contamination Within and Around Nuclear Power Plants: Origin, Distribution, Inventory, and Decommissioning Assessment, PNL-SA-11600, Pacific Northwest Laboratory, Richland, Washington, 1984 .

7. J. C. Evans, et al., Long-Lived Activation Products in Reactor Materials, NUREG/CR-3274, Pacific Northwest Laboratory for U.S. Nuclear Regulatory Commission, Washington, D.C., December 1983. 


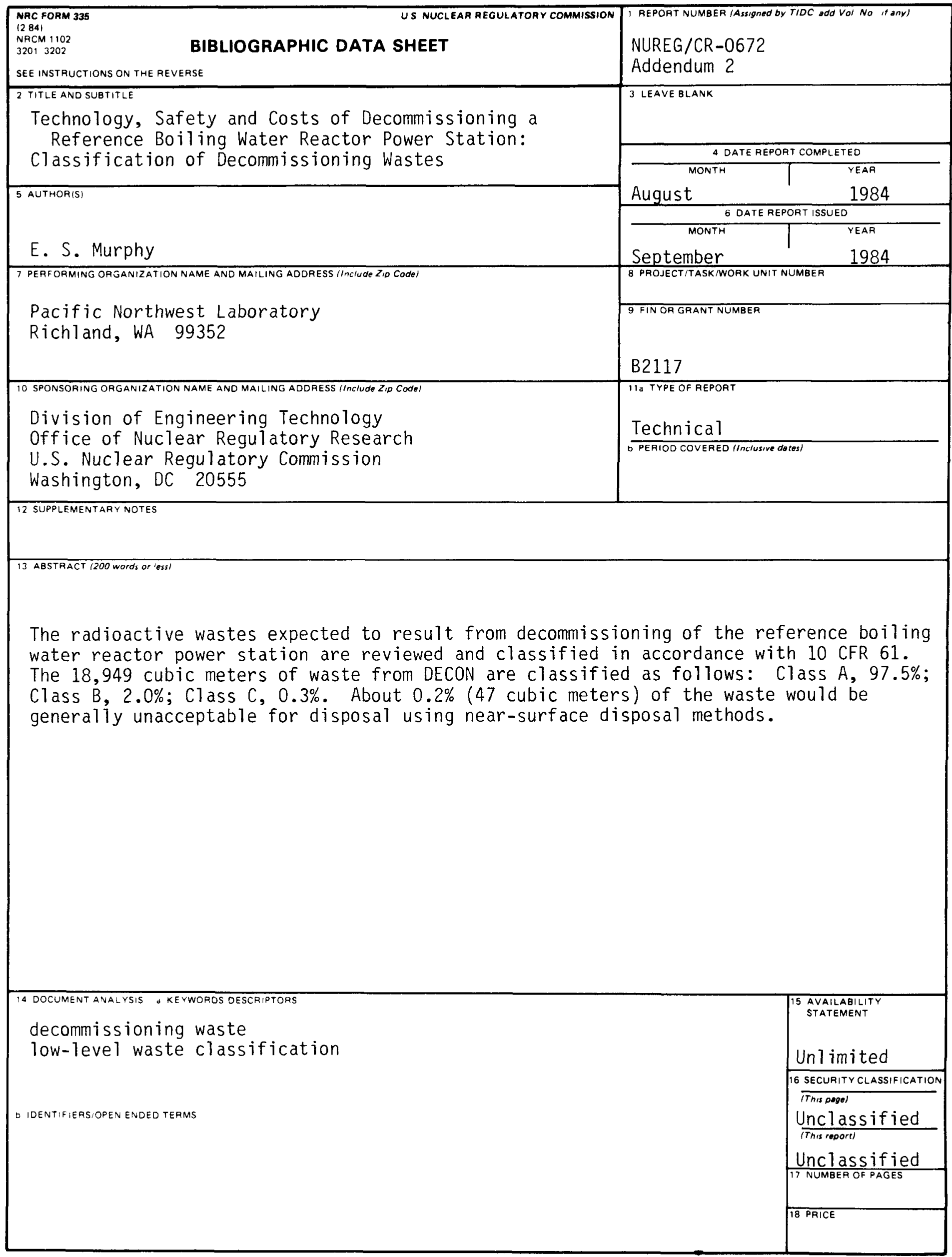

